\title{
The neuroprotective effects of icariin on ageing, various neurological, neuropsychiatric disorders, and brain injury induced by radiation exposure
}

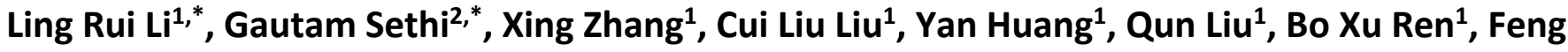 \\ Ru Tang ${ }^{3}$ \\ ${ }^{1}$ The School of Basic Medicine, Health Science Center, Yangtze University, Jingzhou 434023, Hubei, China \\ ${ }^{2}$ Department of Pharmacology, Yong Loo Lin School of Medicine, National University of Singapore, Singapore \\ 117600 , Singapore \\ ${ }^{3}$ Radiation Physiology Lab, Singapore Nuclear Research and Safety Initiative, National University of Singapore, \\ Singapore 138602, Singapore \\ ${ }^{*}$ Equal contribution
}

Correspondence to: Bo Xu Ren, Feng Ru Tang; email: boxuren188@163.com, https://orcid.org/0000-0002-3294-3260; snrtfr@nus.edu.sg

Keywords: icariin, oxidative stress, neuroinflammation, ageing, radio-neuro-protective effect

Received: October 18, $2021 \quad$ Accepted: February 8, $2022 \quad$ Published: February 14, 2022

Copyright: (C) $2022 \mathrm{Li}$ et al. This is an open access article distributed under the terms of the Creative Commons Attribution License (CC BY 3.0), which permits unrestricted use, distribution, and reproduction in any medium, provided the original author and source are credited.

\begin{abstract}
Epimedium brevicornum Maxim, a Traditional Chinese Medicine, has been used for the treatment of impotence, sinew and bone disorders, "painful impediment caused by wind-dampness," numbness, spasms, hypertension, coronary heart disease, menopausal syndrome, bronchitis, and neurasthenia for many years in China. Recent animal experimental studies indicate that icariin, a major bioactive component of epimedium may effectively treat Alzheimer's disease, cerebral ischemia, depression, Parkinson's disease, multiple sclerosis, as well as delay ageing. Our recent study also suggested that epimedium extract could exhibit radio-neuroprotective effects and prevent ionizing radiation-induced impairment of neurogenesis. This paper reviewed the pharmacodynamics of icariin in treating different neurodegenerative and neuropsychiatric diseases, ageing, and radiation-induced brain damage. The relevant molecular mechanisms and its anti-neuroinflammatory, antiapoptotic, anti-oxidant, as well as pro-neurogenesis roles were also discussed.
\end{abstract}

\section{INTRODUCTION}

Icariin (molecular formula: $\mathrm{C} 33 \mathrm{H} 40 \mathrm{O} 15$, molecular weight: $676.67 \mathrm{~g} / \mathrm{mol}$ ) [1], a prenylated flavonoid glycoside, is derived from the Chinese herb Epimedium sagittatum [2] or yin yang huo [3]. Epimedium is a Traditional Chinese Medicine (TCM) used for thousands of years [1]. In Asian countries, it is used as a traditional tonic agent for ageing, male sexual dysfunction, and major human body systems [4]. The essential components of epimedium include icariin, icaritin, desmethylicaritin, icariside I, and icariside II.
As a primary component of epimedium, icariin has many pharmacological effects, including treatment of impotence [5], ameliorating sexual dysfunction, promoting estrogen synthesis [6], and osteoporosis. Moreover, icariin can exhibit both immunomodulatory and anti-inflammatory effects [7], antioxidant activity [4], anti-ageing [8], improvement of cardiovascular function, in addition to be anti-bacterial [9] and antitumor [10-13]. It has been used in the management of hypertension, coronary heart disease, osteoporosis, menopausal syndrome, rheumatism, neurasthenia, bronchitis, and hypogonadism (Figure 1) [14]. 
Moreover, recent studies have also suggested that icariin produces neuroprotective effects and can significantly increase the viability of hippocampal neurons treated with corticotropin releasing hormone (CRH) for $24 \mathrm{~h}$ [15]. It alleviates the cognitive deficits in the senescence accelerated mouse prone 8 (SAMP8) Alzheimer's disease (AD) animal model by inhibiting the formation of amyloid plaques through the downregulation of amyloid-beta 1-42 (A $\beta 1-42)$, suppression of neuronal death as well as promoting apoptosis by increasing the B-cell lymphoma 2 (Bcl2)/Bax ratio [16]. It also protects sodium azide $\left(\mathrm{NaN}_{3}\right)$ induced neurotoxicity in $\mathrm{PC} 12$ cells by activating the phosphoinositide 3-kinase/protein kinase B/glycogen synthase kinase-3 $\beta$ (PI3K/Akt/GSK-3 $\beta)$ signaling pathway [17]. In this paper, we reviewed the

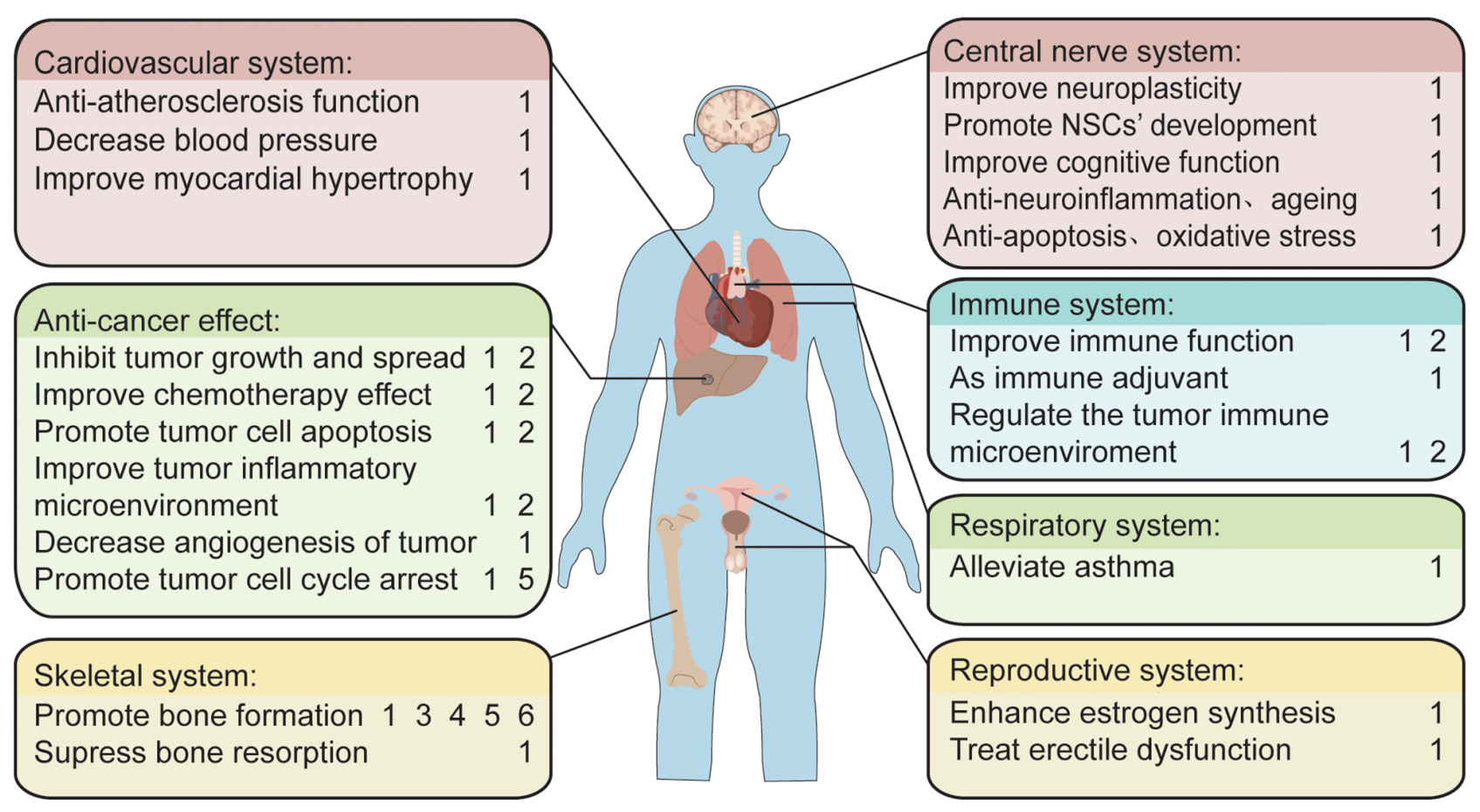

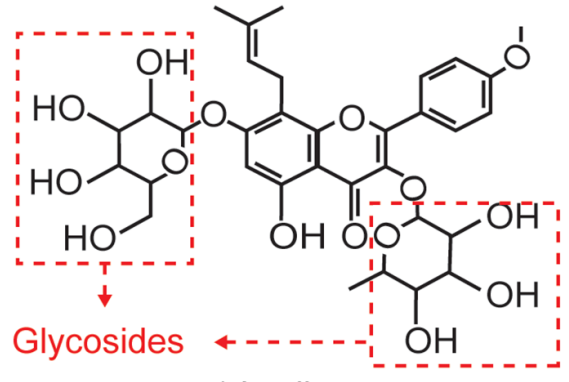

1 Icariin<smiles>COc1ccc(-c2oc3c(CC=C(C)C)c(OC4OC(CO)C(O)C(O)C4O)cc(O)c3c(=O)c2O)cc1</smiles>

4 Icariside I<smiles>COc1ccc(-c2oc3c(CC=C(C)C)c(O)c(=O)c=3c(O)cc2O)cc1</smiles>

2 Icaritin<smiles>COc1ccc(-c2oc3c(CC=C(C)C)c(O)cc(O)c3c(=O)c2OC2OC(C)C(O)C(O)C2O)cc1</smiles>

5 Icariside II<smiles>CC(C)=CCc1c(O)cc(O)c2c(=O)c(O)c(-c3ccc(O)cc3)oc12</smiles>

3 Desmethylicaritin<smiles>CC(C)=CCc1c(OC2OC(CO)C(O)C(O)C2O)cc(O)c2c(=O)c(O)c(-c3ccc(O)cc3)oc12</smiles>

6 Epimedoside C

Figure 1. The pharmacological effects of the main components of epimedium and the related chemical formula. In terms of function, icariin plays a protective and anti-tumor role in various cardiovascular, skeletal, central nervous, immune, respiratory, and reproductive systems. Structurally, icariin has a chemical structure of glycosides, which is one of the reasons for its low oral bioavailability. 
pharmacological effects of icariin on different neurological and neuropsychiatric disorders, ionizing radiation-induced brain damage and their relevant molecular mechanisms.

\section{Pharmacodynamics of icariin in neurodegenerative diseases}

Neurodegenerative diseases are incurable and patients are in debilitating conditions with progressive degeneration or death of nerve cells, which may cause problems with movement or mental functioning. Neurodegenerative diseases, including brain trauma, brain ischemia, AD, Parkinson's disease (PD), multiple sclerosis (MS) and Prion disease, Motor neuron diseases (MND), Huntington's disease (HD), Spinocerebellar ataxia (SCA), are caused by the loss of neurons or their myelin sheath [18]. The leading causes of neurodegeneration include oxidative stress, mitochondrial dysfunction, excitatory neurotoxicity, immune inflammation, and apoptosis [19]. Extensive studies have shown that icariin has anti-angiogenesis, anti-autophagy, anti-apoptosis, anti-inflammatory as well as anti-oxidative effects and promotes neurogenesis [1].

\section{AD}

$\mathrm{AD}$ has an increasing prevalence globally because of the ageing of the global population [20-22]. The characteristic of $\mathrm{AD}$ includes memory deficits and cognitive decline which has brought serious economic and psychological burden to the patient family and society [23]. The neuropathological changes of $A D$ include abnormal deposition of $\mathrm{A} \beta$, neurofibrillary tangles, hypofunction of cholinergic neurons, loss of synapses, dendritic spines, and regionally specific neuronal apoptosis in the brain [24, 25]. So far, the pathogenesis of $\mathrm{AD}$ has not been accurately elucidated and there is no suitable drug to effectively prevent or reverse AD's pathological process [26, 27]. Icariin has been found to cross the blood-brain barrier, exert a neuroprotective effect [28], and improve the spatial learning and memory ability in different animal models $[25,29]$. It can effectively improve memory dysfunction by restoring atrophies of axons and dendrites even when amyloid $\beta$-induced neurite atrophy has already occurred in $5 \times \mathrm{FAD}$ mouse model [30]. A $\beta$ plaque is the most significant pathological marker of AD. Preventing or slowing down the formation of $A \beta$ is an efficient therapy to $\mathrm{AD}$ development [31]. $\mathrm{A} \beta$ is produced in the brain by transmembrane amyloid precursor protein (APP) cleaved sequentially by $\beta$-site amyloid precursor protein cleaving enzyme 1 (BACE1) and $\gamma$-secretase complex [32]. Thus, inhibition of APP, BACE1 and $\gamma-$ secretase expression may be closely related to the decrease of $A \beta$ production. A number of previous studies has shown that icariin enhances the ability of spatial learning and memory by reducing the A $\beta 1-40$ and beta-secretase and increasing superoxide dismutase2 in A 325 -35-induced rat model [33]. Icariin decreased the expression of APP, BACE1 and reduced $\mathrm{A} \beta$ deposition in APP/PS1 Tg mouse model [34]. Moreover, icariin could significantly decrease the expression of APP and A $\beta$ and increase neurogenesis in Tg2576 mouse model [26]. These findings further support the important role of icariin in the prevention and treatment of $\mathrm{AD}$.

Accumulating evidences suggest that hyperphosphorylation of Tau protein is an early event in the development of $\mathrm{AD}$, which leads to neurotoxic effects and ultimately neurodegeneration [35]. Therapy to inhibit tau hyperphosphorylation has gradually become a treatment to prevent the development of $\mathrm{AD}$ [36]. GSK-3 $\beta$ is one of the significant tau kinases in tau protein hyperphosphorylation [37]. The GSK-3 $\beta$ expression level is higher in APP transgenic cultures, and thereby suppressing GSK-3 $\beta$ expression may reduce $A \beta$-induced toxicity of hyperphosphorylated tau. Icariin exerts neuroprotective effects on PC12 cells treated with A $\beta 25-35$ by inhibiting hyperphosphorylation of tau through suppressing the PI3K/Akt-dependent GSK-3 $\beta$ signaling pathway [35]. Therefore, icariin may be a candidate drug for the treatment of $\mathrm{AD}$ and other tau protein abnormalities.

Vascular risk factors and cerebrovascular injury may increase the risk of $\mathrm{AD}$ genesis [31]. Long-term chronic cerebral hyperperfusion is a key factor in the development of degenerative brain lesions and $\mathrm{AD}$ related pathology [38]. Icariin can alleviate cognitive impairment in permanent bilateral ligation of the common carotid arteries (2-VO) rat model [39]. Aluminum reduces the learning and memory ability by inducing brain damage in the rat model leading to the pathogenesis of $\mathrm{AD}$ [40]. Icariin improves the learning and memory impairment of rats induced by aluminum and reverses the decrease of superoxide dismutase (SOD) activity and the increase of malondialdehyde (MDA) level in the hippocampus of rats under aluminum exposure [41]. In animal models of $A D$, abnormal brain nitric oxide/soluble guanylate cyclase/ cyclic guanosine monophosphate/protein kinase G/cyclic adenine monophosphate responsive element binding protein $(\mathrm{NO} / \mathrm{sGC} / \mathrm{cGMP} / \mathrm{PKG} / \mathrm{CREB})$ signaling pathway is observed [42]. Phosphodiesterase 5 (PDE5) is a cGMP degrading enzyme, and PDE5 inhibitors can improve synaptic plasticity and memory function by increasing cGMP and thereby activating $\mathrm{NO} / \mathrm{sGC} / \mathrm{cGMP} / \mathrm{PKG} / \mathrm{CREB}$ signaling pathway [42]. In APP/PS1 Tg mouse model, icariin improved the 
learning and memory functions by inhibiting PDE5 activity and activating NO/cGMP signaling [43]. These results indicate that icariin may act as a potent therapeutic agent against AD. Further studies are still needed to analyze the therapeutic potential of icariin in large animal model and patients with $\mathrm{AD}$.

\section{PD}

$\mathrm{PD}$, a progressive neurodegenerative disorder with the loss of dopaminergic neurons in the midbrain substantia nigra [44] is characterized by slow movement, static tremor, rigidity, and posture instability [45, 46]. PD patients also show autonomic, cognitive, psychiatric and sleep dysfunctions $[47,48]$. The main etiology of PD includes gene mutations and 1-methyl-4-phenyl-1,2,3,6tetrahydropyridine (MPTP) exposure. PD may also be related to heredity, environment and ageing [48]. Due to the complex pathogenesis of PD, no ideal therapeutic drug with few side effects has been developed so far. Some traditional herbs show beneficial effects on PD [49], which have led to active research in this field. For instance, icariin was found to reduce the loss of dopaminergic (DA) neurons in the substantia nigra pars compacta (SNpc), suppress the expression of Bax and Caspase-3, increase the levels of Bcl-2 in the striatum in MPTP-induced PD mouse model [50]. Chen et al. (2016) confirmed that PI3K/Akt and MEK/extracellular signal-regulated kinase (ERK) signaling pathways were involved in the neuroprotective effect of icariin in both in vivo and in vitro models [50]. These results suggest that icariin may be one of the candidate herbs for PD treatment.

It has been established that neuroinflammation caused by glial activation is related to the pathogenesis of PD [51]. Icariin has been shown to protect DA neurons from lipopolysaccharide/6-hydroxydopamine (LPS/6OHDA) damage, improve motor performance, reduce microglial activation, decrease tumor necrosis factor- $\alpha$ (TNF- $\alpha$ ), interleukin-1 $\beta$ (IL-1 $\beta$ ), and NO production by inhibiting nuclear factor- $\mathrm{KB}(\mathrm{NF}-\mathrm{\kappa B})$ signaling pathway under both in vitro and in vivo settings [52]. Although $\mathrm{NF}-\mathrm{KB}$ is a key factor involved in neuroinflammation, other factors related to neuroinflammation cannot be ignored. Nuclear factor erythroid 2 related factor 2 (Nrf2) has been proved to have anti-inflammatory properties [53]. A number of recent studies has demonstrated that icariin protects DA neurons against 6-OHDA and suppresses the glia cells-elicited neuroinflammation through activating Nrf2 signaling [54]. The above studies show that icariin may reduce neuroinflammation by inhibiting NF-KB pathway or activating Nrf2 signaling pathway. Further study in different animal models of PD may be needed in order to imitate different features of PD patients, so that more effective drugs could be developed to control patient's symptoms.

\section{Ischemia and Stroke}

Cerebral ischemia may be caused by stroke, anemia, and cardiovascular diseases leading to neuronal damage as well as impairment of brain functions [55]. The molecular mechanisms involved may include glutamate-mediated/induced excitotoxicity, reactive oxygen species production, DNA damage, regulation of pro-apoptotic factors [56]. So far, there is still no drug to control ischemia-induced brain damage effectively. Some bioactive components from herbs, such as icariin, appear to have neuroprotective roles after ischemia [55]. In the rat brain ischemia-reperfusion model, icariin effectively prevents neuronal damage and improves animal cognition $[57,58]$.

Cerebral ischemia activates microglia and induces microglia to produce inflammatory mediators to aggravate brain tissue damage [59]. In a cerebral ischemia-reperfusion (I/R) injury model induced by middle cerebral artery occlusion (MACO), Xiong et al. (2016) reported that icariin significantly improved I/Rinducibility and reduced the infarct volume by its antiinflammation effect through markedly down-regulating the levels of IL- $1 \beta$ and TGF- $\beta 1$ proteins by inhibition of $\mathrm{NF}-\mathrm{KB}$ activation. Furthermore, icariin was found to increase both peroxisome proliferator-activated receptors $\alpha(\mathrm{PPAR} \alpha)$ and PPAR $\gamma$ protein expression in the brain tissue. These results indicated that icariin may prevent brain ischemic injury by targeting on both PPAR $\alpha$ and PPAR $\gamma$ [60]. Icariin may also significantly improve the learning and memory by activation of cholinergic system and the scavenging of oxygen free radicals [61]. It reduces 6-OHDA-induced neurotoxicity by stimulating Nrf2 antioxidative signaling pathways in PC12 cells [19], and protects mouse primary cortical neurons after oxygen and glucose deprivation (OGD), which may be partially associated with the increase of sirtuin 1 (SIRT1) via the activation of mitogen-activated protein kinase (MAPK)/p38 signaling pathway [62]. Moreover, icariin also reduces brain ischemic injury by upregulating SIRT1-dependent peroxisome proliferatoractivated receptor $\gamma$ coactivator- $1 \alpha$ (PGC- $1 \alpha)$ expression [63]. These studies strongly suggest that icariin is a promising neuroprotectant to treat ischemic- or strokeinduced brain injury and subsequent neurocognitive impairment.

\section{Depression}

Depression has once been considered a disease often suffered by middle-aged women. It now becomes a public health problem that affects people of different 
ages and economic backgrounds [64]. Patients with depression have severe mood disorders; such as persistent feeling of sadness, loss of interest and concentration [65]. In some cases, patients may hurt themselves, causing an increased rate of disability and suicide [66, 67]. Depression limits the victim's psychosocial functions and reduces the quality of life [68]. Psychological and drug treatments have been used to control syndromes. For mild-to-moderate depression, psychotherapeutic intervention is a preferred method [69]. Antidepressants have been the primary treatment for depression. So far, the pathophysiology of depression is still unclear. It may be linked to a decline in the function of the monoaminergic neurotransmitters (serotonin, norepinephrine, dopamine, or combined) in the brain, as antidepressants targeted on these neurotransmitters can effectively mitigate the functional impairments [70]. However, the clinical efficacy of these drugs is rather limited with some side effects [55, 67, 68]. Icariin has been considered a promising antidepressant with minimum adverse effects [55]. In the rodent models of depression, icariin decreased immobility time in the forced swim test and tail suspension test $[28,71,72]$, indicating its potential anti-depressive effects. Notably, icariin reversed the elevated oxidase monoamine oxidase $\mathrm{A}$ and $\mathrm{B}$ levels and the decreased monoamine neurotransmitter levels in the brain caused by the forced swim test [72]. In addition, icariin was recently reported to improve hippocampal neurogenesis in a rat model of depression [73] (Figure 2).

The association between the abnormalities of the hypothalamic-pituitary-adrenal (HPA) axis and depression has been established in the previous study [74]. The anti- depressant-like activity of icariin may be linked to its regulation on the central neuroendocrine system or the abnormal HPA axis [55]. In rats exposed to chronic mild stress (CMS), Pan et al. (2010) found that icariin could down-regulate the levels of serum corticotropin-releasing factor (CRF) and corticosterone (CORT) as well as decrease the levels of CRF mRNA and protein in the hypothalamus [75]. These results suggested that icariin could reverse CRF system hyperactivity, which was further proved in the subsequent studies on rats exposed to chronic unpredictable mild stress (CUMS) [76]. Moreover, icariin has been shown to decrease FK506 binding protein 5 (FKBP5) mRNA levels in serum and glucocorticoid-inducible kinase 1 (SGK-1) in the hippocampus and prefrontal cortex. Icariin partially reversed the upregulated expression of nuclear GR in the prefrontal cortex and that of FKBP5 in the hippocampus. It may therefore restore the negative feedback function of the HPA axis and produce antidepressant-like effects [77].
High concentrations of CORT induce cell apoptosis, leading to the neuronal damage and subsequent depression-like behavior. Accumulated evidence indicates that the antidepressant-like activity of icariin may be related to its anti-CORT-induced apoptosis. In primary cultured rat hippocampal neurons, icariin produces a neuroprotective effect against CORTinduced apoptosis and mitochondrial dysfunction through blockade of p38 MAPK phosphorylation [78]. In addition, icariin pretreatment restores CORT-induced abnormity in caspase-3 activity, intracellular reactive oxygen species and superoxide dismutase activity, mitochondrial membrane potential, and the loss of neurons by activating the PI3K/Akt pathway in primary cultured hypothalamic neurons [79].

It is important to highlight that neuroinflammation may play an important role in the development of depression $[80,81]$. LPS induces pro-inflammatory factors in the immune cells of animals, such as TNF- $\alpha$, IL- $1 \beta$, and interleukin-6 (IL-6), which in turn cause depression-like behaviors [81, 82]. The possible mechanisms involved may include the increase of oxidative stress $[82,83]$ and the activation of the brain-derived neurotrophic factor (BDNF) signaling pathway [84]. Recent studies have suggested the importance of icariin as the antineuroinflammatory agent that produces significant antidepressant effects. In neuron-microglia co-culture system, icariin decreased LPS-induced proinflammatory mediators such as prostaglandin E (PGE)2 , NO, TNF- $\alpha$, IL-1 $\beta$, IL-6, and cyclooxygenase-2 $(\mathrm{COX}-2)$, in activated microglia by the inhibition of JNK/p38 MAPK and TGF- $\beta$ activated kinase-1 (TAK1)/I $\kappa B$ kinase (IKK)/NF- $\mathrm{KB}$ signaling pathways [85]. In rats with LPS-induced brain dysfunction, icariin reduces escape latency and the searching distance in the Morris water maze (MWM) test, suggesting improved spatial learning and memory. Meanwhile, it decreases brain COX-2, IL-1 $\beta$, and TNF- $\alpha$ levels [86]. In an unpredictable chronic mild stress model of depression, icariin restrains activation of the nod-like receptor protein 3 (NLRP3) inflammasome and elevation of IL$1 \beta$ and caspase-1 protein levels in the rats' hippocampus, as well as activation of NF-KB signaling and increase of oxidative-nitrosative stress markers [28]. Icariin has also been shown to attenuate immobility in the forced swim test and normalize hippocampal BDNF levels in a rat model of CORTinduced depression [87]. In a social defeat mouse model, icariin reverses the translocation of High mobility group protein box 1 (HMGB1) from the nucleus to the cytoplasm, which has been found to be involved in stress-induced inflammation [88]. These studies strongly suggest that the neuroprotective effects of icariin may be partially related to its antineuroinflammatory effect. 
Icariin may also produce an antidepressant-like effect by affecting neurotransmission system. In the prenatal restraint stress (PRS)-induced depression rat model, icariin relieves PRS-induced depressive-like behavior accompanied by a decrease in excitatory amino acid transporter 2 (EAAT2), metabotropic glutamate receptor 1 and 5 (mGluR1 and mGluR5) expressions in the hippocampus [14]. In rats with depression induced by CORT, glucose metabolism decreases in the brain, and the depression-like behaviors are improved when the glucose metabolism level is increased after treatment with icariin [89, 90]. In other models of depression, abnormal amino acid and lipid metabolism were observed in the hippocampus, cortex, and thalamus [91, 92]. Icariin increased amino acid, glucose, and lipid metabolism in the rat model of

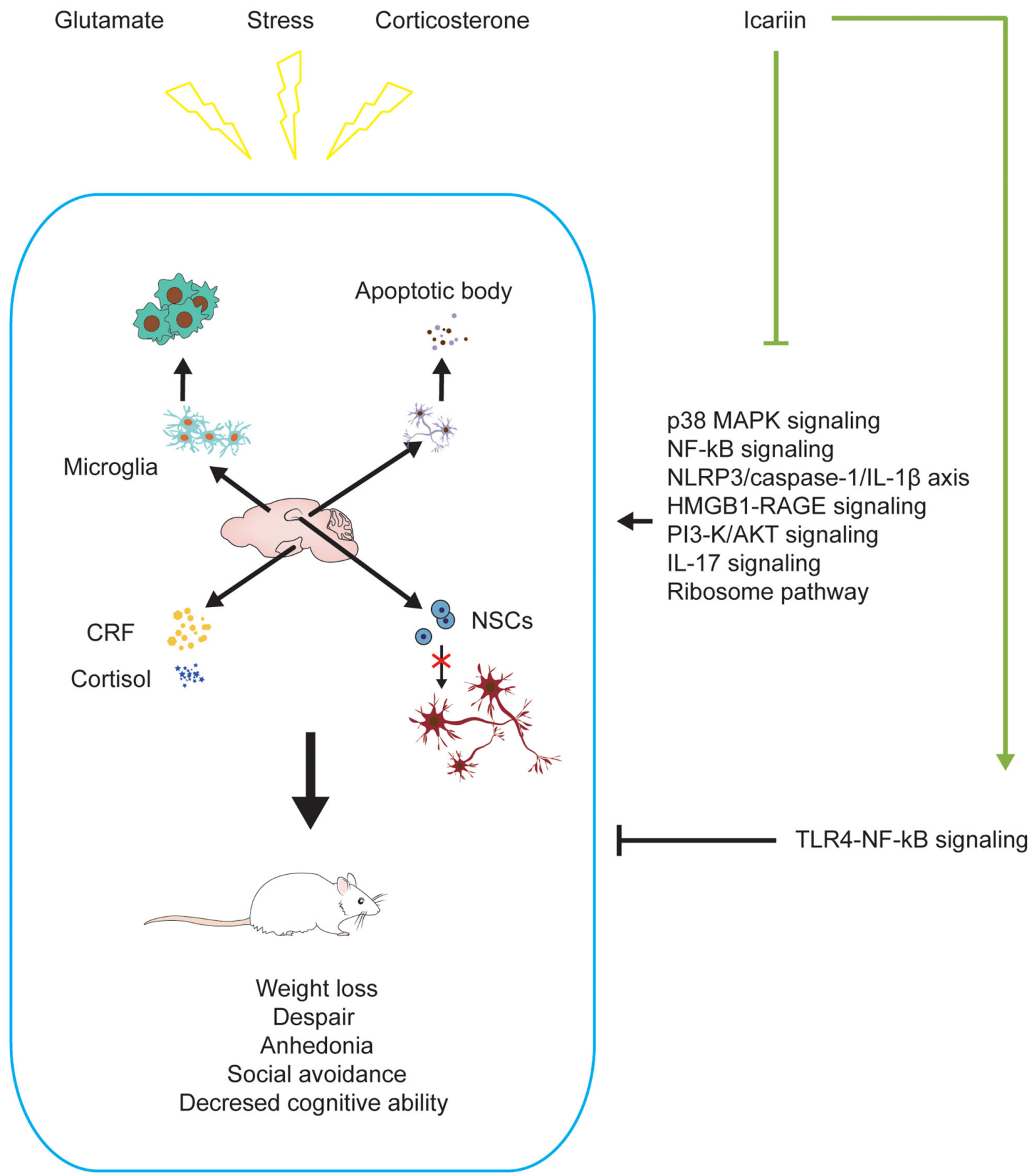

Figure 2. Icariin alleviates depression-like changes induced by stress, corticosterone, and glutamate in depressive models. Icariin can downregulate the levels of apoptosis, neuroinflammation, CRF, cortisol and promote neurogenesis in the brain to improve the depression-like behaviors. The mechanisms may be inhibiting P38 MAPK, NF-KB, HMGB1-RAGE, PI3-K/AKT, IL-17, ribosome signaling pathways, NLRP3/Caspase-1/IL-1 $\beta$ axis, and activating TLR4-NF-KB signaling pathway. 
CORT-induced depression [87]. These findings suggest that icariin may be used as a candidate drug to treat depression-like behavior by regulating abnormal metabolic pathways.

\section{MS}

MS is an autoimmune disease with inflammation, demyelination, and axon damage as the main neuropathological changes in the CNS [93]. It is common in young people and has many main clinical manifestations that appear singly or in combination, such as vision loss or diplopia, limb weakness or sensory loss, or ataxia [94]. At present, the specific pathogenesis of MS is unknown. Several important factors such as the Epstein-Barr virus, smoking, ultraviolet radiation B (UVB), vitamin D, and genetic background have been reported to be involved in pathogenesis of the disease [93]. Clinical treatment of MS is limited to symptomatic relief, hormone therapy, and immunosuppressant medicine may cause severe complications $[95,96]$. In a commonly used experimental autoimmune encephalomyelitis (EAE) MS model, icariin and methylprednisolone (a CORT) produces a synergistic effect to enhance anti-inflammatory functions [96]. In addition, icariin promotes myelin regeneration and axonal repair during the remission period by increasing oligodendrocyte numbers and nerve growth factor levels in the cuprizone-induced acute demyelination model [97].

The central nervous system inflammatory infiltration by $\mathrm{T}$ cells is accompanied by microglial activation in multiple sclerosis, leading to oligodendrocyte reduction and demyelination [93]. Icariin reduces the number of Th1 and Th17 cells in spleen and lymph nodes, Th17 cells in CNS in EAE mouse model, and inhibits $\mathrm{T}$ cell proliferation and Th1 and Th17 cell differentiation in vitro [98]. Icariin attenuates clinical scores, improves demyelination, and reduces inflammation by inhibiting the activation of CNS inflammatory pathways such as the NF-KB pathway in another EAE mouse model of MS [99]. However, Wei et al. (2016) reported that icariin only decreased CORT but not IL-17 level in the EAE mouse model [95]. The difference may be due to the MS model used by different laboratories and further studies are still needed to clarify the inconsistency of results among different research groups.

There are evidences to suggest that the regulation of the HPA axis is related to the progression, severity, and prognosis of MS [100]. Glucocorticoid is the end product of the HPA axis, CORT is the main glucocorticoid in rodents, and its level partly reflects the activity of the HPA axis [101]. Because of the antiinflammatory effects of glucocorticoids, activation of the HPA axis in MS plays a neuroprotective role.
However, hyperactivity of the HPA axis is also associated with severe neurodegeneration, and low activity of the HPA axis seems to be consistent with a more active MS lesion [100, 101]. In EAE mouse models, icariin produces synergistic effects with MP to reduce IL-17 and CORT levels in serum [96]. In addition, icariin alone reduces the mean clinical score of EAE mice with significantly reduced serum CORT levels [95]. These experimental data indicate that icariin may serve as a novel drug to treat MS.

\section{Pharmacodynamics of icariin on ageing}

Ageing, a common physical progress with decreased regeneration, body resistance, and increased disease susceptibility [102], causes physical changes like skin pigmentation, body contraction, organ failure. Ageing has become an issue of growing concern globally, and it is crucial and necessary to find new therapeutic guidelines to fight ageing. In addition, the new approaches should not only aim to prolong the life expectancy but also keep a fit body [103]. In ancient China, many emperors sought immortality by taking elixir, but they all failed. Today, increasing evidences indicate that some herbs can delay ageing [104]. Icariin produces significant beneficial effects in both in vitro and in vivo models of ageing. It may reduce cell senescence and improve the spatial memory in SAMP8 model [105] (Figure 3).

Ageing is often accompanied by neurodegeneration, and there are some similar mechanisms between ageing and neurodegeneration, such as oxidative stress, neurogenesis, and neuroinflammation. Therefore, it is reasonable to assume that preventing and delaying ageing may also slow down the occurrence and development of neurodegeneration. The brain may be the most vulnerable organ in the whole ageing process of the human body due to its high oxygen consumption and low antioxidant capacity [106]. Brain ageing decreases memory ability and cognitive function and increases senescent cells and neuronal loss [107]. Icariin reduces the impairment of the spatial memory in the SAMP8 mouse model. Senescence-associated $\beta$-galactosidase $\quad$ (SA- $\beta$-gal) staining demonstrated that icariin could delay the ageing progress of brain cells [105]. The hippocampus acts an important role in cognitive function [108]. The rate of neurogenesis in the hippocampus declines with age, and this decline has been closely associated with cognitive decline in mammals and humans [109, 110]. Icariin improves cognitive function in natural ageing rats via a potential mechanism associated with activating quiescent neural stem cells [111].

SIRTs are nicotinamide adenine nucleotide (NAD+)dependent deacetylases, which participate in the cell 
cycle, gene repair, metabolism, and oxidative stress $[112,113]$. In yeast, Drosophila, Caenorhabditis elegans (C. elegans), mice, and human beings, Sirts are highly expressed and related to lifespan extension [114116]. In old (24-month-age) male C57BL/6J mice, icariin increased the decline of Sirt 1, 3, and 6 proteins induced by ageing in the brain [117].

In addition, several studies have proved that ageing is accompanied by dysfunctional autophagy [118]. Icariin reduces neuronal dysfunction in ageing rats by promoting neuronal autophagy through the AMPK/mTOR/ULK1 pathway [119]. Icariin could ameliorate the motor and learning disabilities of male $\mathrm{C} 57 \mathrm{BL} / 6 \mathrm{~J}$ ageing mice by activating Akt/Nrf2/NF-kB signaling pathway [117].

\section{Pharmacodynamics of icariin after radiation exposure}

Human beings are exposed to natural radiation, i.e., terrestrial radioactivity and indoor radon, at an annual average individual effective dose of about $2.4 \mathrm{mSv}$ and

\section{Ageing model}
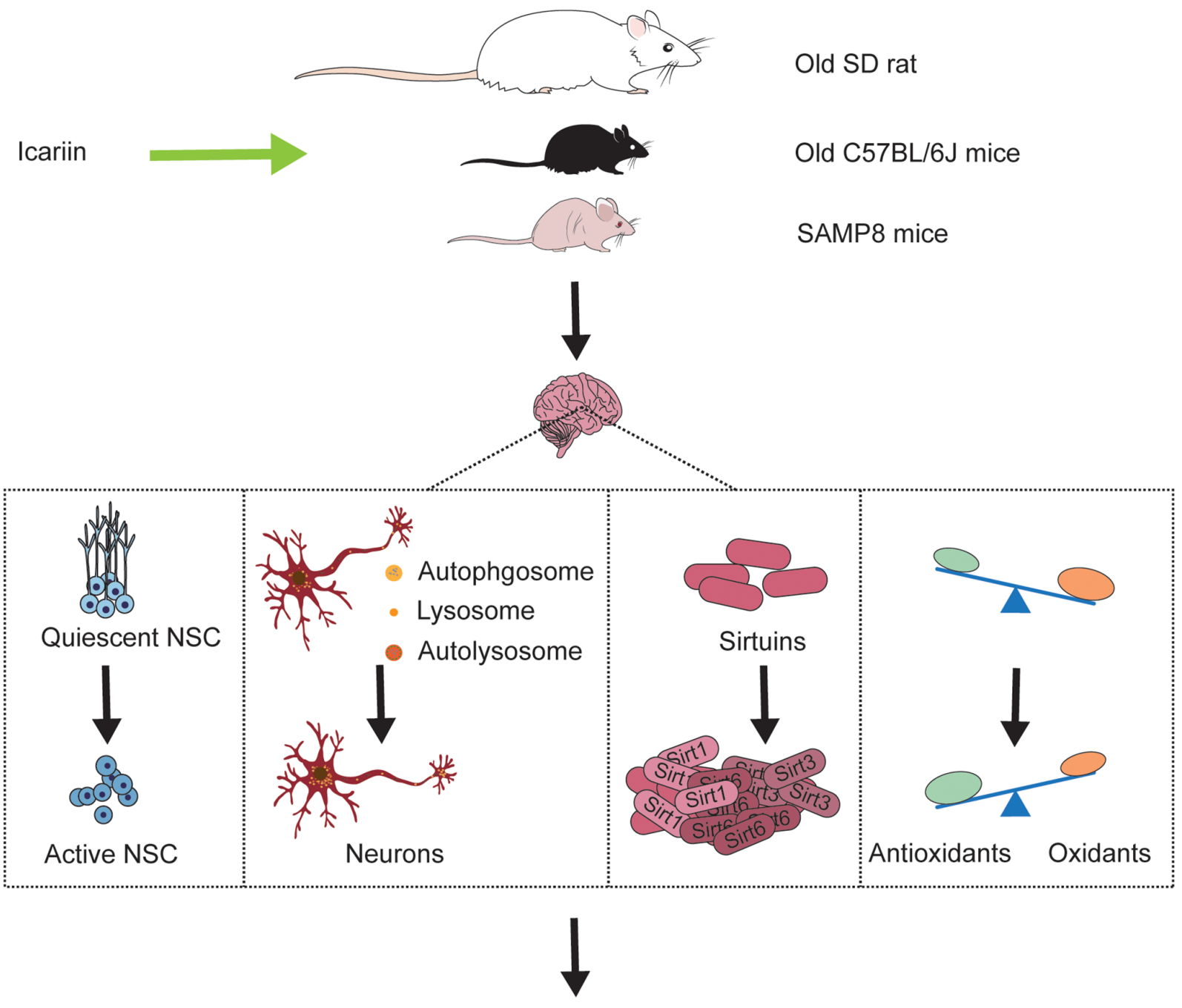

- Prolonged lifespan

- Improved cognitive ability

- Improved motor coordination

Figure 3. Icariin reverses ageing-induced deficits in the brain of ageing models. Icariin not only prolongs life span of ageing animals but also improves cognitive function and motor coordination by promoting neurogenesis, enhancing neuronal autophagy, increasing sirtuins protein like Sirt1, Sirt3, Sirt6, and exerting antioxidant effect in the brain. 
artificial radiation. The latter includes X-rays from Xray machines, computed tomography (CT examination), and positron emission tomography (PET scan) (PET/CT scan) for medical diagnosis and radiotherapy [120, 121]. Exposure to high dose/dose radiation rates may cause different cancer and non-cancerous diseases such as cataract, atherosclerotic, cardiovascular, cerebrovascular, and neurodegenerative diseases [122]. Low dose/dose rate radiation may also cause damage to the human body, inducing cancer $[121,123]$, cardiovascular disease [124], cataract [125], neuropsychiatric disorders [126]. Nowadays, radiotherapy is a universal treatment for the brain and head-and-neck cancers [127] but with side effects such as impairments of cognition, language acquisition, and visual spatial ability $[128,129]$, in particular, in young patients as the developing brain is more radiosensitive [128-130].

Amifostine/ethyol, 2-(3-aminopropyl) aminoethylphosphorothioate is the only radioprotective drug approved by the US Food and Drug Administration (FDA). It is used as a reliever for xerostomia after radiotherapy for head and neck tumors [131]. However, due to its side effects such as vomiting, drowsiness, hypotension, and limited administration mode (currently only approved for intravenous administration), the clinical use of amifostine is very limited [132, 133]. Moreover, amifostine is inactive in the brain [134]. Therefore, it is imperative to find a novel radio-neuro-protective drug to prevent irradiationinduced brain injury.

Icariin protects radiosensitive organs such as reproductive and digestive organs from radiation damage and has radiosensitization effect on some cancer cells. In a ${ }^{60} \mathrm{Co}-\gamma$-ray-induced mouse model of spermatogenic disturbance, icariin combined with lycium barbarum polysaccharide and resveratrol promoted spermatogenesis and sperm motility [135]. In vitro study indicated that icariin treatment improved the radiosensitivity of colorectal cancer cells by inhibiting NF-кB signaling [136]. Similarly, icaritin, a hydrolysate of icariin, also synergistically enhanced the radiosensitivity of 4T1 breast cancer cells [137]. Icariin and icaritin have also been reported to inhibit UVBinduced photoaging by activating Nrf2/ARE signaling, suppressing JNK's and ERK's phosphorylation as well as NF-KB's expression [138]. In a recent study, icariin was found to significantly increase bone marrow mesenchymal stem cells (MSCs) regeneration and repair pancreatic injury in L-arginine $/ \gamma$-ray-caused rat model of chronic pancreatitis [139].

In the $\mathrm{BALB} / \mathrm{C}$ mouse model, epimedium extract treatment reduced acute radiation-induced impairment of neurogenesis in the subgranular zone (SGZ) of the dentate gyrus (DG) and improved animal learning and memory ability. Moreover, epimedium treatment prevents radiation-induced weight loss, depression, and spatial memory impairment [140]. Icariin has been found to ameliorate radiation-induced toxicity in the intestine and testis of male C57BL/6 after whole body radiation by X-ray [141]. Therefore, it appears that icariin may be a candidate drug to protect against radiation-induced injury (Table 1). Given the limited research data, future study on radio-neuro-protective effect of icariin is still needed.

\section{Molecular mechanisms of the effect of icariin in brain}

\section{Icariin-mediated autophagy-related effects}

Some environmental toxicants may induce PD, especially pesticides. Rotenone (ROT) is one of the pesticides with neurotoxicity that affects the normal course of autophagy $[142,143]$ and has been considered to be related to the genesis or development of PD and reduced DA neurons in PD [144]. In a rat PD model induced by ROT, icariin significantly reduced neurotoxicity by activating autophagy in the brain [144]. Intra-cephalic $A \beta$ accumulation has been related to $\mathrm{AD}$ development $[21,145] . \mathrm{A} \beta$ produced in endonuclear and autophagic vacuoles may be effectively transmitted to other organelles by lysosomal proteolysis. In $\mathrm{AD}$, the dysfunction of autophagic vacuoles or lysosomal proteolysis induces $A \beta$ deposition in the brain [146]. In addition, the formation of elevated $A \beta$ deposition is caused by inhibition of basal autophagy, resulting in neurodegeneration [142]. Hence, the regulation of autophagy dysfunction may be a good strategy for $\mathrm{AD}$ patients. Icariin reduces the cognitive impairments and autophagic dysfunction in the rat $\mathrm{AD}$ model induced by intracerebroventricular (icv) injection of A $\beta 1-42$ [143]. Mechanistic studies have shown that icariin reduce oxygen-glucose deprivation and reperfusion (OGD/R)-induced high level of autophagy by increasing the level of Bcl-2 and decreasing the Beclin-1 and LC3-II levels in OGD/Rtreated PC12 cells [147]. In a rat model of natural ageing, icariin improves autophagy in the brain by regulating AMPK/mTOR/ULK1 signaling pathway.

\section{Anti-apoptotic effect of icariin}

Excitotoxicity causes neuronal death and is involved in the development of $\mathrm{AD}$ [24]. Neurodegeneration is an important pathological characteristic of AD [148]. Intracerebroventricular injection of excitatory neurotoxin ibotenic acid triggers caspase family and causes apoptosis leading to irreversible damage in the 
Table 1. Radioprotective effect of icariin.

\begin{tabular}{|c|c|c|c|c|c|c|c|}
\hline No. & Model & $\begin{array}{l}\text { Radiation type } \\
\text { and dosage }\end{array}$ & $\begin{array}{c}\text { Drug and } \\
\text { dosage }\end{array}$ & $\begin{array}{l}\text { Dosing } \\
\text { period }\end{array}$ & Effect & Mechanism & References \\
\hline 1 & $\begin{array}{l}\text { Mouse model of } \\
\text { spermatogenic } \\
\text { disturbance } \\
\text { induce by } \\
{ }^{60} \mathrm{Co} \gamma \text {-ray }\end{array}$ & $\gamma$-ray; 6 Gy & $\begin{array}{l}\text { Icariin, Lycium } \\
\text { barbarum } \\
\text { polysaccharide } \\
\text { and resveratrol; } \\
80 \mathrm{mg} / \mathrm{kg} \\
\text { respectively }\end{array}$ & 60 days & $\begin{array}{l}\text { Promoted } \\
\text { spermatogenesis and } \\
\text { sperm motility }\end{array}$ & Did not mention. & [126] \\
\hline 2 & $\begin{array}{l}\text { Colorectal } \\
\text { cancer cell } \\
\text { lines: HCT116 } \\
\text { and HT29; } \\
\text { Xenograft } \\
\text { Mouse Model }\end{array}$ & $\begin{array}{l}\text { X-ray; } 0,2,4,6 \\
\text { Gy in vitro and } \\
4 \text { Gy in vivo }\end{array}$ & $\begin{array}{l}\text { Icariin; } 25 \mathrm{uM} \text { in } \\
\text { vitro and } 40 \\
\mathrm{mg} / \mathrm{kg} \text { in vivo }\end{array}$ & $\begin{array}{l}4 \mathrm{~h} \text { in } \\
\text { vitro and } \\
3 \text { weeks in } \\
\text { vivo }\end{array}$ & $\begin{array}{l}\text { Enhanced the } \\
\text { radiation-mediated } \\
\text { anti-proliferative } \\
\text { effect; exerted the } \\
\text { anti-proliferative } \\
\text { and/or pro-apoptotic } \\
\text { effect possibly }\end{array}$ & $\begin{array}{l}\text { Inhibited the } \\
\text { activation of NF- } \\
\text { KB signaling } \\
\text { pathway }\end{array}$ & [127] \\
\hline 3 & $\begin{array}{l}\text { Murine 4T1 } \\
\text { breast cancer } \\
\text { cells }\end{array}$ & $\begin{array}{l}\text { IR; } 0,1,4,6, \\
8 \mathrm{~Gy}\end{array}$ & $\begin{array}{l}\text { Icaritin; } 0,1.5, \\
3,6,12.5,13,25 \\
\text { uM }\end{array}$ & $\begin{array}{l}4,24,48, \\
72 \mathrm{~h}\end{array}$ & $\begin{array}{l}\text { Exert an anti- } \\
\text { proliferative effect; } \\
\text { induce the G2/M } \\
\text { blockage of } 4 \mathrm{~T} 1 \\
\text { cells; Synergize } \\
\text { with IR to enhance } \\
\text { 4T1 cell apoptosis }\end{array}$ & $\begin{array}{l}\text { Suppressed the } \\
\text { activation of } \\
\text { ERK1/2 and } \\
\text { AKT signaling } \\
\text { pathways }\end{array}$ & [128] \\
\hline 4 & $\begin{array}{l}\text { UVB-irradiated } \\
\text { human } \\
\text { keratinocytes } \\
\text { (HaCaTs) }\end{array}$ & $\begin{array}{l}\mathrm{UVB} ; 125 \\
\mathrm{~mJ} / \mathrm{cm}^{2}\end{array}$ & $\begin{array}{l}\text { Icariin and } \\
\text { icaritin;1, 10, } \\
100 \mathrm{nM} \\
\text { respectively }\end{array}$ & $24 \mathrm{~h}$ & $\begin{array}{l}\text { Produced anti- } \\
\text { oxidative stress, } \\
\text { anti-inflammation } \\
\text { and anti- } \\
\text { photoageing effects }\end{array}$ & $\begin{array}{l}\text { Promoted } \\
\text { Nrf/ARE } \\
\text { signaling; } \\
\text { inhibited JNK } \\
\text { and ERK } \\
\text { phosophorylatio; } \\
\text { suppressed NF- } \\
\text { KB expression }\end{array}$ & [129] \\
\hline 5 & $\begin{array}{l}\text { Chronic } \\
\text { pancreatitis rat } \\
\text { model induced } \\
\text { by L- } \\
\text { arginine/radiati } \\
\text { on }\end{array}$ & $\gamma$-ray; 6 Gy & $\begin{array}{l}\text { Icariin; } 100 \\
\mathrm{mg} / \mathrm{kg}\end{array}$ & 8 weeks & $\begin{array}{l}\text { Promoted MSCs } \\
\text { proliferation and } \\
\text { differentiation; } \\
\text { Synergize with } \\
\text { MSCs to improve } \\
\text { the function of } \\
\text { pancreatic stellate } \\
\text { cells }\end{array}$ & Did not mention & [130] \\
\hline 6 & $\begin{array}{l}\text { X-ray-irradiated } \\
\text { BALB//C } \\
\text { mouse model }\end{array}$ & X-ray; 5.5 Gy & $\begin{array}{l}\text { Epimedium } \\
\text { extract; } 5 \mathrm{~g} / \mathrm{kg}\end{array}$ & 4 weeks & $\begin{array}{l}\text { Improved animal } \\
\text { weight loss, } \\
\text { locomotor activity } \\
\text { and spatial learning } \\
\text { and memory }\end{array}$ & & [131] \\
\hline 7 & $\begin{array}{l}\text { X-ray-irradiated } \\
\text { C57BL/6 mice }\end{array}$ & $\begin{array}{l}\text { X-ray; } 4 \text { and } 7 \\
\text { Gy }\end{array}$ & $\begin{array}{l}\text { Icariin; } 10,20 \\
40 \mathrm{mg} / \mathrm{kg}\end{array}$ & $\begin{array}{l}24 \mathrm{~h} \text { and } \\
30 \mathrm{~min} \\
\text { before and } \\
24 \mathrm{~h} \text { after } \\
\text { irradiation }\end{array}$ & $\begin{array}{l}\text { Protected the } \\
\text { radiosensitive } \\
\text { organs such as } \\
\text { intestine, testis and } \\
\text { hemopoietic system }\end{array}$ & $\begin{array}{l}\text { Produced effect } \\
\text { partly through its } \\
\text { anti-oxidative } \\
\text { and anti- } \\
\text { apoptotic } \\
\text { properties }\end{array}$ & [132] \\
\hline
\end{tabular}

hippocampus [149]. Icariin significantly increases procaspase- 3 expression and decreases active-caspase- 3 in the rat ibotenic acid-induced excitotoxicity model, suggesting its neuroprotective effect by reducing neuronal apoptosis [24]. Moreover, in the APP/PS1 transgenic mice model, icariin reduces apoptotic cells induced by endoplasmic reticulum (ER) stress through suppressing the protein kinase RNA-like ER kinase/eukaryotic initiation factor $2 \alpha$ (PERK/Eif2 $\alpha$ pathway) in the hippocampus [150]. In vitro study indicates that icariin protects hypothalamic neurons from apoptosis by the activation of PI3K/Akt signaling pathway [79]. These results are consistent with the previous reports that icariin inhibits CORT-caused rat hippocampal neuronal apoptosis by inhibiting the p38 MAPK signaling pathway [78], and suppresses ER stress-induced neuronal apoptosis by activating the PI3K/Akt signaling pathway [151]. In PC12 cells model of ER stress, anti-apoptotic effects of icariin may partially be associated with the up-regulation of synoviolin, an essential anti-apoptotic factor that inhibits cell death caused by ER stress [152].

Hydrogen peroxide $\left(\mathrm{H}_{2} \mathrm{O}_{2}\right)$-induced oxidative stress may cause apoptosis by activating JNK/p38 MAPK pathways [153]. p53, a transcription factor, may be 
associated with neuronal apoptosis regulation [154]. The neuronal apoptosis will start when p53 is activated, and p53 activation is closely related to the $\mathrm{JNK} / \mathrm{P} 38$ MAPK pathway. In addition, JNK/p38 MAPK from MAPKs family is related to the anti-oxidation process. It may serve as an important target for treating oxidative stress-induced neurodegenerative diseases [155]. Activation of JNK/p38 MAPK induces cellular apoptosis [156]. Under $\mathrm{H}_{2} \mathrm{O}_{2}$ exposure, phosphorylation of JNK/p38 MAPK occurs in PC12 cells. Pretreatment of icariin reduces the number of neuronal apoptosis by inhibiting the phosphorylation of JNK/p38 MAPK pathway, suggesting that neuroprotective effect of icariin may be mediated through inhibition of JNK/p38 MAPK signaling pathway [157].

Akt, also known as protein kinase B, is the crucial downstream factor of PI3K. The phosphorylation of Akt plays a vital role in the PI3K/Akt signaling pathway $[158,159]$, it regulates various substrates, such as GSK$3 \beta, \mathrm{Bcl}-2$ [160] and is involved in the pathogenesis of different brain diseases, including AD [161], epilepsy [162], and cerebral ischemia [163]. Activation of PI3K signaling prevents many apoptosis stimuli [164]. In PD animal model induced by MPTP, icariin effectively protects mouse from neurotoxicity and reduce the occurrence of neuronal apoptosis in the substantia nigra accompanied by decreased Bcl-2, increased Bax, and caspase 3 protein expressions, as well as the increased phosphorylation levels of Akt. In addition, these neuroprotective effects may be blocked by LY294002 (a PI3K inhibitor) [50], which indicates that the PI3K/Akt signaling pathway may contribute to icariin's anti-apoptotic effect. The anti-apoptotic effect of icariin may also be regulated by the inositol-requiring enzyme1/X-box-binding protein-1 (IRE1/XBP1) pathway in the OGD/R cell model [165].

\section{Anti-oxidant effects of icariin}

Oxidative stress is an imbalance in which the production of reactive oxygen species in the body far exceeds the body's anti-oxidant capacity [106]. When oxidative stress occurs, lipid peroxidation damages the cell membrane, induces irreversible changes in the structure and function of some proteins (e.g., structural proteins and enzyme proteins), and DNA damage [106]. The brain is an organ that needs high energy and high oxygen due to its abundant peroxidable polyunsaturated fatty acids, high concentration of reactive oxygen catalyst iron, relative lack of anti-oxidant enzymes, and susceptible to oxidative stress [166].

Oxidative stress induced by $\mathrm{H}_{2} \mathrm{O}_{2}$ is an important contributor to the pathogenesis of AD [157]. Hydrogen peroxide belongs to the high reactive oxygen species
(ROS). It causes neuronal apoptosis by activating relevant molecular pathways when oxidative stress is induced $[153,167]$. Icariin prevents hydrogen peroxideinduced PC12 cells death, suggesting that it has an antioxidant effect [157]. The anti-oxidant effect of icariin to $\mathrm{H}_{2} \mathrm{O}_{2}$-induced cytotoxicity may be related to the upregulation of SIRT1 [168]. Moreover, icariin may reverse the upregulation of MDA and downregulation of SOD activity in 2-VO rats, leading to neuroprotection [61]. In an unpredictable CMS rat model of depression, icariin produces antidepressantlike effect partially by mediating the anti-oxidation process [61]. In $\mathrm{AD}$ mouse model, icariin attenuates excess iron-induced brain oxidative stress [61]. In addition, icariin partially reverses learning and memory impairments induced by aluminum, which may also be associated with its anti-oxidant effect [41]. In vitro study indicates that icariin may decrease ROS production in LPS-treated microglia [85].

Nrf2 regulates important genes, such as promoter regulatory regions, enabling cells to maintain a stable situation from oxidative stress, inflammation, and biotransformation [169]. Nrf2 is considered a crucial transcription factor that modulates cellular redox state in the case of oxidative stress [170]. Moreover, substantial evidence indicates that loss of Nrf2 may be involved in the development of neurodegenerative diseases. In addition, Nrf2 inactivation has been associated with ageing and PD [171]. In the 6-OHDAinduced neurotoxicity of $\mathrm{PC} 12$ cell model, icariin attenuates the accumulation of reactive oxygen species and improve the survival rate by introducing more active Nrf2. These results suggest that icariin may serve as an anti-oxidant by the activation of Nrf2 pathway [19].

\section{Anti-neuroinflammatory effects of icariin}

Microglia-mediated neuroinflammation plays a key part in the pathogenesis of neurodegenerative diseases. Accumulating evidences show that inhibition of neuroinflammation may effectively mitigate neurodegenerative diseases [172]. Neuroinflammation is characterized by the activation of glial cells, especially microglial activation leading to a significant increase of inflammatory cytokines and chemokines [173]. Icariin inhibits glia-mediated neuroinflammation by activating Nrf2 signaling in both in vitro and in vivo models $[85,172]$. In the mouse models of LPS-induced hippocampal neuroinflammation and social defeat, icariin exerts an anti-neuroinflammatory effect by inhibiting HMGB1-receptor for advanced glycation end products (RAGE) signaling [65, 174]. In CUMSinduced rat model of depression, icariin produces antineuroinflammatory and anti-depression effect partially 
by the inhibition of NF-KB pathway and the NLRP3inflammasome/caspase-1/IL-1 $\beta$ axis [28]. In APP/PS1 transgenic mice, icariin also reduces neuroinflammation induced by microglial activation in the cortex [175]. Icariin may also reduce neuroinflammatory response in LPS-stimulated microglia by suppressing the TAK1/IKK/NF- $\mathrm{KB}$ and JNK/p38 MAPK signaling [85]. In addition, icariin protects DA neuronal damage induced by LPS and 6-OHDA, which is partially regulated by its suppression of microglia-mediated neuroinflammation [52].

\section{Icariin promotes neurogenesis}

In the mammalian brain, the process by which neural stem cells (NSCs) proliferate and differentiate into new cells such as astrocytes, neurons, and oligodendrocytes is called neurogenesis [176-178]. Adult neurogenesis mainly occurs in discrete brain areas such as the SGZ of the DG and the subventricular zone (SVZ) adjacent to the lateral ventricles $[179,180]$. Decreased neurogenesis in the hippocampal $\mathrm{DG}$ region of $\mathrm{AD}$ animal models has been well documented [181-184]. Promoting neurogenesis may significantly improve hippocampal-dependent cognitive function [185-188]. In Tg2576 mice, Icariin promotes hippocampal neurogenesis and improves memory ability [26]. In SD rat model of cerebral ischemia, icariin and mesenchymal stem cells (MSCs) synergistically improve neurogenesis [189]. In vitro studies show that icariin promotes human NSC proliferation by regulating the various related genes [190] and the growth and proliferation of NSCs in cultured rat hippocampus by regulating the levels of cyclin D1 and p21, which exert an important effect in modulating cell cycle [191]. NSCs are divided into quiescent NSCs and active NSCs [192], and the activation of quiescent NSCs increases neurogenesis. In the rat ageing model, icariin induces the transformation of quiescent NSCs into active NSCs [111]. It enhances the proliferation, viability, and migratory ability of NCSs in vitro, promotes their differentiation into neurons in vivo [193] and facilitates the self-renewal of NSCs by regulating ERK/MAPK signaling pathway [152].

\section{Icariin produces neuroprotective effects by modulating various other signal transduction pathways}

SIRTs are a small family of proteins, comprising of SIRT1-SIRT7 [30]. In ageing and other pathological processes, SIRTs are involved in regulating transcription, cell cycle, cell differentiation, apoptosis, stress, metabolism, and genome stability [194]. Among family members, SIRT1 is an important molecule that has been associated with neuronal stress response [63].
Under ischemia/reperfusion circumstances, SIRT1 may protect cortical neuronal damage by inhibiting p53 [195]. Moreover, SIRT1 extends lifespan through increasing gene stability in lower organisms such as yeast and mammals [196]. In addition, SIRT3, another important member of SIRTs, which exists in mitochondria, regulates mitochondrial function by modifying protein in many tissues including the brain [197]. SIRT3 protects neurons from an oxidative stress injury in mitochondria and prolongs the lifespan of the neurons [198]. SIRT3 is related to neurodegenerative diseases such as AD, PD, HD [199]. Moreover, in neurons, PGC-1 family is a powerful stimulator of mitochondrial respiration and gene transcription [200]. It has been reported that PGC- $1 \alpha$, a member of PGC- 1 family, regulates mitochondrial function [201] by inducing mitochondrial gene expression and mediating energy metabolism [202]. Additionally, elevated PGC$1 \alpha$ level reduced neuronal death caused by oxidative stress [203]. In rats and PC12 cells, the expression of PGC- $1 \alpha$ reduces with the decrease of SIRT3 after ROT treatment [199]. In addition, ICA alleviates ROTinduced oxidative stress toxicity by modulating mitochondrial antioxidant SOD2 through increasing the levels of SIRT3 and PGC-1 $\alpha$ [199]. Overexpression of SIRT1 activates PGC-1 $\alpha$ to regulate neuronal metabolism and mitochondrial function [200, 204, 205]. Icariin produces neuroprotective effects in ischemic brain injury [63]. In stroke model, PGC- $1 \alpha$ increases parallel to the SIRT1 after icariin treatment. The neuroprotective effect of icariin could be reversed by a SIRT1 inhibitor [63]. Therefore, the activation of SIRTs-PGC- $1 \alpha$ signaling pathway may contribute to the neuroprotection of icariin.

ERK is actively involved in the Ras-Raf-ERK pathway and related to cell development and proliferation [206]. In the mammalian brain, ERK may be involved in the process of dendritic protein synthesis, which plays a vital role in memory and long-term potentiation (LTP) formation [207]. $\mathrm{Ca}^{2+} /$ calmodulin-dependent protein kinase II alpha (CaMKII $\alpha$ ), a protein kinase with multiple functions, is highly expressed in the hippocampus. In terms of learning and memory and LTP in particular, CaMKII $\alpha$ plays a significant role [208]. CREB is a downstream protein of CaMKII, the transcription of CREB and CaMKII is conducive to neuronal plasticity and development. The impaired learning and memory function induced by chronic multiple-stress is improved through the elevation of CREB and CaMKII mRNA expression in the brain [208]. In prenatally stressed female offspring, reduced spatial learning and memory and working memory ability are demonstrated by MWM test and 8-Arm Maze. These animals also show downregulated expression of CaMKII $\alpha$ and CREB in the hippocampus 
[209]. Treatment with icariin improves animal learning and memory and upregulates hippocampal CaMKII $\alpha$, CREB, and ERK [209]. These results strongly suggest that icariin can effectively alleviate the influence of prenatal stress on rat offspring by the activation of ERK/CaMKII $\alpha /$ CREB pathway.

The detailed molecular mechanisms underlying icariin's neuroprotective effects have been indicated in Figure 4.

\section{CONCLUSIONS AND FUTURE STUDIES}

Animal experimental studies have strongly suggested the neuroprotective effects of icariin on neurological and neuropsychiatric diseases, brain ageing, and injury induced by radiation exposure. These neuroprotective effects are mainly mediated through regulation of neuroinflammation, neuronal apoptosis, and autophagy. Recent studies have indicated that icariin may also be used to treat brain diseases such as prenatal stressinduced offspring cognitive impairment [209], demyelinating disease [210], and MS [99]. An icariinNGSTH (nanogel loaded self-assembled thermosensitive hydrogel) has been developed to effectively control the depression by continuous release of icariin through adhesion of nasal mucosa in vivo [71]. The ethosomal gel of icariin combined with hydroxysafflor yellow A (HSYA), Epimedin B, and 3, 4-dihydroxybenzoic acid could be used to treat

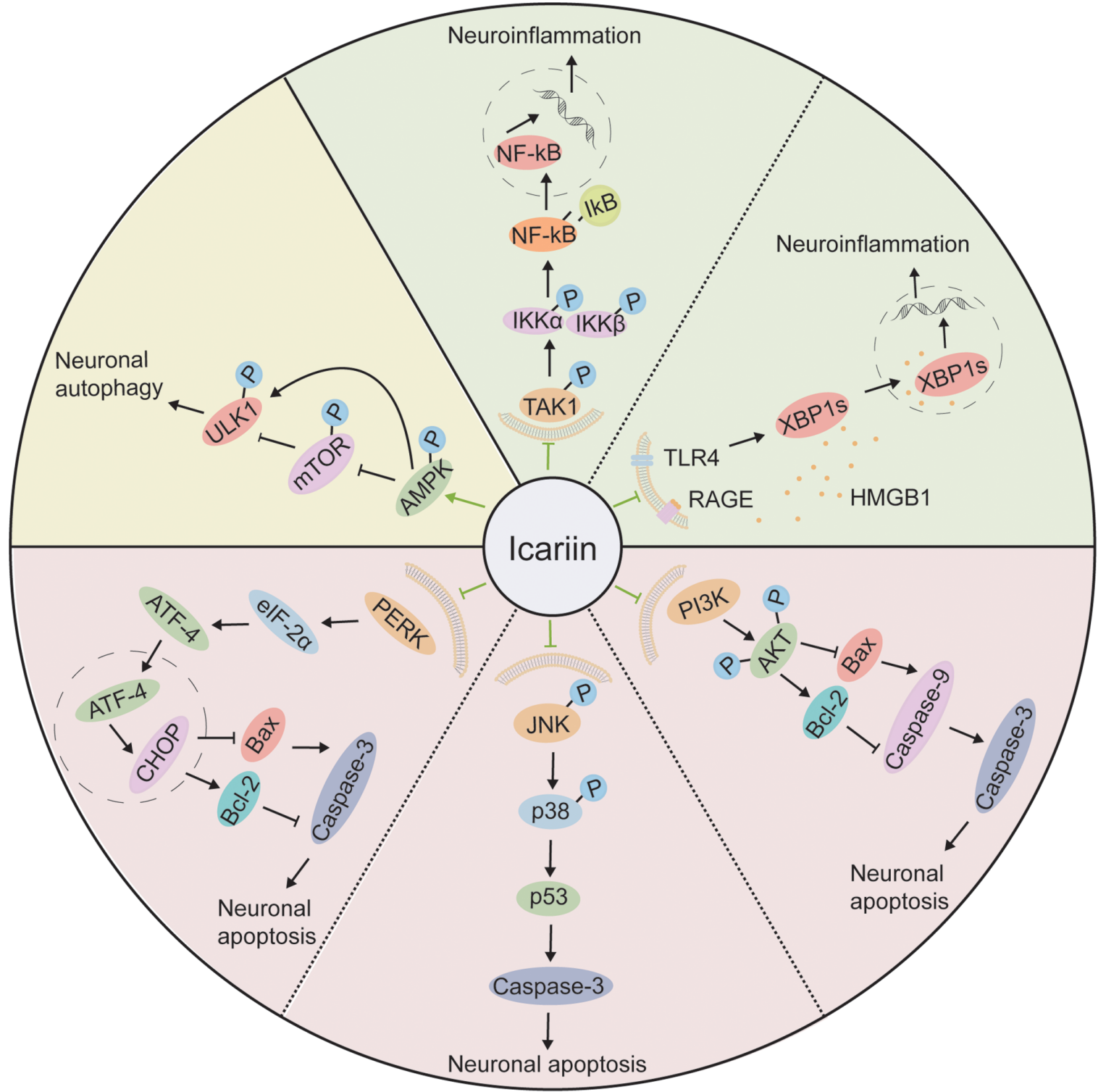

Figure 4. The molecular mechanisms of the neuroprotective effect of icariin. Icariin improves neuronal autophagy through the AMPK/mTOR/ULK1 pathway; It attenuates neuroinflammation by inhibiting TAK1/IKK/NF-KB and HMGB1/RAGE pathways; It reduces neuronal apoptosis by suppression of PERK/elF2 $\alpha$, JNK/p38 MAPK, and PI3K/AKT pathways. 
peripheral neuropathy caused by oxaliplatin [211]. Icariin has also been found to exert an antiatherosclerosis effect by regulating some pathways involving lncRNA (Lon non-coding RNA) and mRNA [212], suggesting its neuroprotective roles may also be regulated by lncRNA and mRNA.

Further studies in the following areas may still be needed: 1) development of a novel delivery system in order to increase the efficiency of icariin to enter the CNS and effectively treat brain diseases; 2) understanding the roles of icariin on non-coding RNAs such as microRNAs, IncRNAs, in order to target them to effectively prevent the genesis of different brain diseases; and 3) investigation of the effect of icariin on gut microbiota so as to reveal novel mechanisms of icariin on gut-brain-axis, and its therapeutic effects on the different neurological, neuropsychiatric disorders and brain radiation exposure.

\section{Abbreviations}

TCM: Traditional Chinese Medicine; CRH: corticotropin releasing hormone; SAMP8: senescence accelerated mouse prone 8; AD: Alzheimer's disease; A $\beta$ : amyloid-beta; Bcl-2: B-cell lymphoma 2; $\mathrm{NaN}_{3}$ : sodium azide; PI3K: phosphoinositide 3-kinase; Akt: protein kinase B; GSK-3 $\beta$ : glycogen synthase kinase$3 \beta$; CNS: central nervous system; PD: Parkinson's disease; MS: multiple sclerosis; MND: Motor neuron diseases; SCA: Spinocerebellar ataxia; HD: Huntington's disease; APP: amyloid precursor protein; BACE1: $\beta$-site APP-cleaving enzyme 1; 2-VO: permanent bilateral ligation of the common carotid arteries; SOD: superoxide dismutase; MDA: malondialdehyde; NO: nitric oxide; sGC: soluble guanylate cyclase; cGMP: cyclic guanosine monophosphate; PKG: protein kinase G; CREB: cyclic adenine monophosphate responsive element binding protein; PDE5: Phosphodiesterase 5; MPTP: 1-methyl4-phenyl-1, 2, 3, 6-tetrahydropyridine; DA: dopaminergic; SNpc: substantia nigra pars compacta; MEK: mitogen-activated protein kinase kinase; ERK: extracellular signal-regulated kinase; LPS: lipopolysaccharide; 6-OHDA: 6-hydroxydopamine; TNF- $\alpha$ : tumor necrosis factor- $\alpha$; IL-1 $\beta$ : interleukin- $1 \beta$; NF-кB: nuclear factor-кB; Nrf2: Nuclear factor erythroid 2 related factor 2; I/R: ischemia-reperfusion; MACO: middle cerebral artery occlusion; PPAR: peroxisome proliferator-activated receptors; OGD: oxygen and glucose deprivation; OGD/R: oxygenglucose deprivation and reperfusion; SIRT: Sirtuin; MAPK: mitogen-activated protein kinase; PGC-1 $\alpha$ : peroxisome proliferator-activated receptor $\gamma$ coactivator-1 $\alpha$; HPA: hypothalamic-pituitary-adrenal; CMS: chronic mild stress; CRF: corticotropin-releasing factor; CORT: corticosterone; CUMS: chronic unpredictable mild stress; FKBP5: FK506 binding protein 5; SGK-1: glucocorticoid-inducible kinase 1; IL-6: interleukin-6; BDNF: brain-derived neurotrophic factor; PGE: prostaglandin E; COX-2: cyclooxygenase2; TAK1: TGF- $\beta$ activated kinase-1; IKK: IкB kinase; NLRP3: nod-like receptor protein 3; HMGB1: High mobility group protein box 1; PRS: prenatal restraint stress; EAAT2: excitatory amino acid transporter 2; mGluR: metabotropic glutamate receptor; UVB: ultraviolet radiation B; EAE: experimental autoimmune encephalomyelitis; SA- $\beta$-gal: senescence-associated $\beta$ galactosidase; NAD+: Nicotinamide adenine nucleotide; C. elegans: Caenorhabditis elegans; CT: computed tomography; PET: positron emission tomography; FDA: US Food and Drug Administration; MSCs: mesenchymal stem cells; SGZ: subgranular zone; DG: dentate gyrus; ROT: Rotenone; icv: intracerebroventricular; OGD/R: oxygen-glucose deprivation and reperfusion; ER: endoplasmic reticulum; PERK: protein kinase RNA-like ER kinase; Eif2 $\alpha$ : eukaryotic initiation factor $2 \alpha ; \mathrm{H}_{2} \mathrm{O}_{2}$ : hydrogen peroxide; IRE1: inositol-requiring enzyme-1; XBP1: Xbox-binding protein-1; ROS: reactive oxygen species; RAGE: receptor for advanced glycation end products; NSCs: neural stem cells; SVZ: subventricular zone; LTP: long-term potentiation; CaMKIIa: $\mathrm{Ca}^{2+} /$ calmodulin-dependent protein kinase II alpha; MWM: Morris water maze; NGSTH: nanogel loaded self-assembled thermosensitive hydrogel; HSYA: hydroxysafflor yellow A; lncRNA: Lon non-coding RNA.

\section{AUTHOR CONTRIBUTIONS}

LRL and GS contributed to acquisition and interpretation of data. BXR and FRT contributed to the structure design and to the conception and design of the study as well as to critical revision for important intellectual content.

\section{CONFLICTS OF INTEREST}

The authors declare no conflicts of interest related to this study.

\section{FUNDING}

This research was funded by the following research grants from the National Natural Science Foundation of China (Grant no. 81772223) to BXR; Grants from Health Commission of Hubei Province scientific research project (Grant no. WJ2021Q015) to LL; Grants from National Research Foundation of Singapore to Singapore Nuclear Research and Safety Initiative (FRT). 


\section{REFERENCES}

1. Angeloni C, Barbalace MC, Hrelia S. Icariin and Its Metabolites as Potential Protective Phytochemicals Against Alzheimer's Disease. Front Pharmacol. 2019; 10:271.

https://doi.org/10.3389/fphar.2019.00271 PMID:30941046

2. Zhang D, Wang Z, Sheng C, Peng W, Hui S, Gong W, Chen S. Icariin Prevents Amyloid Beta-Induced Apoptosis via the PI3K/Akt Pathway in PC-12 Cells. Evid Based Complement Alternat Med. 2015; 2015:235265.

https://doi.org/10.1155/2015/235265

PMID:25705234

3. Yu X, Tong $Y$, Han XQ, Kwok HF, Yue GG, Lau CB, Ge W. Anti-angiogenic activity of Herba Epimedii on zebrafish embryos in vivo and HUVECs in vitro. Phytother Res. 2013; 27:1368-75.

https://doi.org/10.1002/ptr.4881

PMID:23147754

4. Sze SC, Tong Y, Ng TB, Cheng CL, Cheung HP. Herba Epimedii: anti-oxidative properties and its medical implications. Molecules. 2010; 15:7861-70. https://doi.org/10.3390/molecules15117861 PMID:21060294

5. Ma H, He X, Yang Y, Li M, Hao D, Jia Z. The genus Epimedium: an ethnopharmacological and phytochemical review. J Ethnopharmacol. 2011; 134:519-41.

https://doi.org/10.1016/i.jep.2011.01.001 PMID:21215308

6. Yang L, Lu D, Guo J, Meng X, Zhang G, Wang F. Icariin from Epimedium brevicornum Maxim promotes the biosynthesis of estrogen by aromatase (CYP19). J Ethnopharmacol. 2013; 145:715-21. https://doi.org/10.1016/j.jep.2012.11.031 PMID:23261485

7. Zhou J, Wu J, Chen X, Fortenbery N, Eksioglu E, Kodumudi KN, Pk EB, Dong J, Djeu JY, Wei S. Icariin and its derivative, ICT, exert anti-inflammatory, antitumor effects, and modulate myeloid derived suppressive cells (MDSCs) functions. Int Immunopharmacol. 2011; 11:890-8.

https://doi.org/10.1016/i.intimp.2011.01.007 PMID:21244860

8. Zhang SQ, Cai WJ, Huang JH, Wu B, Xia SJ, Chen XL, Zhang XM, Shen ZY. Icariin, a natural flavonol glycoside, extends healthspan in mice. Exp Gerontol. 2015; 69:226-35. https://doi.org/10.1016/j.exger.2015.06.020 PMID:26145038
9. Xiong $\mathrm{W}$, Huang J, Li X, Zhang Z, Jin $\mathrm{M}$, Wang J, Xu Y, Wang $Z$. Icariin and its phosphorylated derivatives alleviate intestinal epithelial barrier disruption caused by enterotoxigenic Escherichia coli through modulate p38 MAPK in vivo and in vitro. FASEB J. 2020; 34:1783-801.

https://doi.org/10.1096/fj.201902265R

PMID:31914584

10. Song L, Chen X, Mi L, Liu C, Zhu S, Yang T, Luo X, Zhang $Q$, Lu $H$, Liang $X$. Icariin-induced inhibition of SIRT6/NF-KB triggers redox mediated apoptosis and enhances anti-tumor immunity in triple-negative breast cancer. Cancer Sci. 2020; 111:4242-56. https://doi.org/10.1111/cas.14648 PMID:32926492

11. Alhakamy NA, Fahmy UA, Badr-Eldin SM, Ahmed OAA, Asfour HZ, Aldawsari HM, Algandaby MM, Eid BG, Abdel-Naim AB, Awan ZA, Alruwaili NK, Mohamed Al. Optimized Icariin Phytosomes Exhibit Enhanced Cytotoxicity and Apoptosis-Inducing Activities in Ovarian Cancer Cells. Pharmaceutics. 2020; $12: 346$.

https://doi.org/10.3390/pharmaceutics12040346 PMID:32290412

12. Tan HL, Chan KG, Pusparajah $P$, Duangjai A, Saokaew $S$, Mehmood Khan T, Lee LH, Goh BH. Rhizoma Coptidis: A Potential Cardiovascular Protective Agent. Front Pharmacol. 2016; 7:362.

https://doi.org/10.3389/fphar.2016.00362 PMID:27774066

13. Jung $Y Y$, Lee JH, Nam D, Narula AS, Namjoshi OA, Blough BE, Um JY, Sethi G, Ahn KS. Anti-myeloma Effects of Icariin Are Mediated Through the Attenuation of JAK/STAT3-Dependent Signaling Cascade. Front Pharmacol. 2018; 9:531.

https://doi.org/10.3389/fphar.2018.00531 PMID:29899697

14. Zhang $X$, Sun H, Su Q, Lin T, Zhang H, Zhang J, Dang S, Zhu Z. Antidepressant-like activity of icariin mediated by group I mGluRs in prenatally stressed offspring. Brain Dev. 2017; 39:593-600.

https://doi.org/10.1016/i.braindev.2017.03.021 PMID:28395974

15. Liu J, Liu L, Sun J, Luo Q, Yan C, Zhang H, Liu F, Wei Y, Dong J. Icariin Protects Hippocampal Neurons From Endoplasmic Reticulum Stress and NF-KB Mediated Apoptosis in Fetal Rat Hippocampal Neurons and Asthma Rats. Front Pharmacol. 2020; 10:1660.

https://doi.org/10.3389/fphar.2019.01660 PMID: $\underline{32082160}$

16. Wu J, Qu JQ, Zhou YJ, Zhou YJ, Li YY, Huang NQ, Deng $\mathrm{CM}$, Luo $Y$. Icariin improves cognitive deficits by reducing the deposition of $\beta$-amyloid peptide and 
inhibition of neurons apoptosis in SAMP8 mice. Neuroreport. 2020; 31:663-71. https://doi.org/10.1097/WNR.0000000000001466 PMID: $\underline{32427716}$

17. Zhang $Y$, Huang $N$, Lu H, Huang J, Jin H, Shi J, Jin F. Icariin protects against sodium azide-induced neurotoxicity by activating the PI3K/Akt/GSK-3 $\beta$ signaling pathway. PeerJ. 2020; 8:e8955.

https://doi.org/10.7717/peerj.8955 PMID: $\underline{32341897}$

18. Solanki I, Parihar P, Mansuri ML, Parihar MS. Flavonoid-based therapies in the early management of neurodegenerative diseases. Adv Nutr. 2015; 6:64-72. https://doi.org/10.3945/an.114.007500 PMID:25593144

19. Zhu L, Li D, Chen C, Wang G, Shi J, Zhang F. Activation of Nrf2 signaling by Icariin protects against 6-OHDAinduced neurotoxicity. Biotechnol Appl Biochem. 2019; 66:465-71. https://doi.org/10.1002/bab.1743 PMID:30892727

20. Wood H. Alzheimer disease: Localized proteomics distinguishes AD subtypes. Nat Rev Neurol. 2017; $13: 260$

https://doi.org/10.1038/nrneurol.2017.41 PMID:28338075

21. Selkoe DJ. Alzheimer's disease: genes, proteins, and therapy. Physiol Rev. 2001; 81:741-66. https://doi.org/10.1152/physrev.2001.81.2.741 PMID: 11274343

22. Wortmann M. Dementia: a global health priority highlights from an ADI and World Health Organization report. Alzheimers Res Ther. 2012; 4:40.

https://doi.org/10.1186/alzrt143 PMID:22995353

23. Ballard C, Gauthier S, Corbett A, Brayne C, Aarsland D, Jones E. Alzheimer's disease. Lancet. 2011; 377:101931.

https://doi.org/10.1016/S0140-6736(10)61349-9 PMID:21371747

24. Zong N, Li F, Deng Y, Shi J, Jin F, Gong Q. Icariin, a major constituent from Epimedium brevicornum, attenuates ibotenic acid-induced excitotoxicity in rat hippocampus. Behav Brain Res. 2016; 313:111-9. https://doi.org/10.1016/j.bbr.2016.06.055 PMID:27368415

25. Sheng C, Xu P, Zhou K, Deng D, Zhang C, Wang Z. Icariin Attenuates Synaptic and Cognitive Deficits in an $A B_{1-42}$-Induced Rat Model of Alzheimer's Disease. Biomed Res Int. 2017; 2017:7464872. https://doi.org/10.1155/2017/7464872 PMID:29057264
26. Li $\mathrm{F}$, Dong $\mathrm{HX}$, Gong $\mathrm{QH}, \mathrm{Wu} \mathrm{Q}$, Jin $\mathrm{F}$, Shi JS. Icariin decreases both APP and $A \beta$ levels and increases neurogenesis in the brain of Tg2576 mice. Neuroscience. 2015; 304:29-35.

https://doi.org/10.1016/i.neuroscience.2015.06.010 PMID:26079110

27. Bachurin SO, Bovina EV, Ustyugov AA. Drugs in Clinical Trials for Alzheimer's Disease: The Major Trends. Med Res Rev. 2017; 37:1186-225. https://doi.org/10.1002/med.21434 PMID:28084618

28. Liu B, Xu C, Wu X, Liu F, Du Y, Sun J, Tao J, Dong J. Icariin exerts an antidepressant effect in an unpredictable chronic mild stress model of depression in rats and is associated with the regulation of hippocampal neuroinflammation. Neuroscience. 2015; 294:193-205.

https://doi.org/10.1016/j.neuroscience.2015.02.053 PMID:25791226

29. Chen YJ, Zheng HY, Huang XX, Han SX, Zhang DS, Ni JZ, He XY. Neuroprotective Effects of Icariin on Brain Metabolism, Mitochondrial Functions, and Cognition in Triple-Transgenic Alzheimer's Disease Mice. CNS Neurosci Ther. 2016; 22:63-73.

https://doi.org/10.1111/cns.12473

PMID:26584824

30. Urano T, Tohda C. Icariin improves memory impairment in Alzheimer's disease model mice (5xFAD) and attenuates amyloid $\beta$-induced neurite atrophy. Phytother Res. 2010; 24:1658-63.

https://doi.org/10.1002/ptr.3183

PMID:21031624

31. Lane CA, Hardy J, Schott JM. Alzheimer's disease. Eur J Neurol. 2018; 25:59-70. https://doi.org/10.1111/ene.13439 PMID:28872215

32. Hampel H, Vassar R, De Strooper B, Hardy J, Willem M, Singh N, Zhou J, Yan R, Vanmechelen E, De Vos A, Nisticò $R$, Corbo $M$, Imbimbo $B P$, et al. The $\beta$ Secretase BACE1 in Alzheimer's Disease. Biol Psychiatry. 2021; 89:745-56.

https://doi.org/10.1016/j.biopsych.2020.02.001 PMID:32223911

33. Nie J, Luo Y, Huang XN, Gong QH, Wu Q, Shi JS. Icariin inhibits beta-amyloid peptide segment 25-35 induced expression of beta-secretase in rat hippocampus. Eur J Pharmacol. 2010; 626:213-8. https://doi.org/10.1016/j.ejphar.2009.09.039 PMID:19782061

34. Zhang L, Shen C, Chu J, Zhang R, Li Y, Li L. Icariin decreases the expression of APP and BACE-1 and reduces the $\beta$-amyloid burden in an APP transgenic 
mouse model of Alzheimer's disease. Int J Biol Sci. 2014; 10:181-91.

https://doi.org/10.7150/ijbs.6232

PMID:24550686

35. Zeng $\mathrm{KW}, \mathrm{Ko} \mathrm{H}$, Yang $\mathrm{HO}$, Wang XM. Icariin attenuates $\beta$-amyloid-induced neurotoxicity by inhibition of tau protein hyperphosphorylation in PC12 cells. Neuropharmacology. 2010; 59:542-50.

https://doi.org/10.1016/i.neuropharm.2010.07.020 PMID:20708632

36. Shahani N, Subramaniam S, Wolf T, Tackenberg C, Brandt R. Tau aggregation and progressive neuronal degeneration in the absence of changes in spine density and morphology after targeted expression of Alzheimer's disease-relevant tau constructs in organotypic hippocampal slices. J Neurosci. 2006; 26:6103-14.

https://doi.org/10.1523/JNEUROSCI.4245-05.2006 PMID: 16738255

37. Hanger DP, Hughes $K$, Woodgett JR, Brion JP, Anderton $\mathrm{BH}$. Glycogen synthase kinase-3 induces Alzheimer's disease-like phosphorylation of tau: generation of paired helical filament epitopes and neuronal localisation of the kinase. Neurosci Lett. 1992; 147:58-62.

https://doi.org/10.1016/0304-3940(92)90774-2 PMID: 1336152

38. Ashok A, Rai NK, Raza W, Pandey R, Bandyopadhyay S. Chronic cerebral hypoperfusion-induced impairment of $A \beta$ clearance requires HB-EGFdependent sequential activation of HIF1 $\alpha$ and MMP9. Neurobiol Dis. 2016; 95:179-93.

https://doi.org/10.1016/j.nbd.2016.07.013 PMID:27431094

39. Li WX, Deng YY, Li F, Liu B, Liu HY, Shi JS, Gong QH. Icariin, a major constituent of flavonoids from Epimedium brevicornum, protects against cognitive deficits induced by chronic brain hypoperfusion via its anti-amyloidogenic effect in rats. Pharmacol Biochem Behav. 2015; 138:40-8.

https://doi.org/10.1016/i.pbb.2015.09.001

PMID:26364923

40. Gong QH, Wu Q, Huang XN, Sun AS, Shi JS. Protective effects of Ginkgo biloba leaf extract on aluminuminduced brain dysfunction in rats. Life Sci. 2005; 77:140-8.

https://doi.org/10.1016/j.Ifs.2004.10.067 PMID: 15862599

41. Luo Y, Nie J, Gong QH, Lu YF, Wu Q, Shi JS. Protective effects of icariin against learning and memory deficits induced by aluminium in rats. Clin Exp Pharmacol Physiol. 2007; 34:792-5. https://doi.org/10.1111/j.1440-1681.2007.04647.x PMID: $\underline{17600559}$

42. Zuccarello E, Acquarone E, Calcagno E, Argyrousi EK, Deng SX, Landry DW, Arancio O, Fiorito J. Development of novel phosphodiesterase 5 inhibitors for the therapy of Alzheimer's disease. Biochem Pharmacol. 2020; 176:113818.

https://doi.org/10.1016/j.bcp.2020.113818

PMID:31978378

43. Jin $F$, Gong $Q H, X u$ YS, Wang LN, Jin H, Li F, Li LS, Ma YM, Shi JS. Icariin, a phosphodiesterase-5 inhibitor, improves learning and memory in APP/PS1 transgenic mice by stimulation of NO/cGMP signalling. Int J Neuropsychopharmacol. 2014; 17:871-81. https://doi.org/10.1017/S1461145713001533 PMID:24513083

44. Stahl K, Rahmani S, Prydz A, Skauli N, MacAulay N, Mylonakou MN, Torp R, Skare $\varnothing$, Berg T, Leergaard TB, Paulsen RE, Ottersen OP, Amiry-Moghaddam M. Targeted deletion of the aquaglyceroporin AQP9 is protective in a mouse model of Parkinson's disease. PLoS One. 2018; 13:e0194896. https://doi.org/10.1371/journal.pone.0194896 PMID:29566083

45. Oertel WH. Recent advances in treating Parkinson's disease. F1000Res. 2017; 6:260. https://doi.org/10.12688/f1000research.10100.1 PMID:28357055

46. Towns CR. The science and ethics of cell-based therapies for Parkinson's disease. Parkinsonism Relat Disord. 2017; 34:1-6.

https://doi.org/10.1016/j.parkreldis.2016.10.012 PMID:28341222

47. Dauer W, Przedborski S. Parkinson's disease: mechanisms and models. Neuron. 2003; 39:889-909. https://doi.org/10.1016/s0896-6273(03)00568-3 PMID:12971891

48. Samii A, Nutt JG, Ransom BR. Parkinson's disease. Lancet. 2004; 363:1783-93. https://doi.org/10.1016/S0140-6736(04)16305-8 PMID: $\underline{15172778}$

49. Srivastav S, Fatima M, Mondal AC. Important medicinal herbs in Parkinson's disease pharmacotherapy. Biomed Pharmacother. 2017; 92:856-63.

https://doi.org/10.1016/i.biopha.2017.05.137 PMID:28599249

50. Chen WF, Wu L, Du ZR, Chen L, Xu AL, Chen XH, Teng $\mathrm{JJ}$, Wong MS. Neuroprotective properties of icariin in MPTP-induced mouse model of Parkinson's disease: Involvement of PI3K/Akt and MEK/ERK signaling pathways. Phytomedicine. 2017; 25:93-9. 
https://doi.org/10.1016/j.phymed.2016.12.017 PMID:28190476

51. Hirsch EC, Standaert DG. Ten Unsolved Questions About Neuroinflammation in Parkinson's Disease. Mov Disord. 2021; 36:16-24. https://doi.org/10.1002/mds.28075 PMID: $\underline{32357266}$

52. Wang GQ, Li DD, Huang C, Lu DS, Zhang C, Zhou SY, Liu J, Zhang F. Icariin Reduces Dopaminergic Neuronal Loss and Microglia-Mediated Inflammation in Vivo and in Vitro. Front Mol Neurosci. 2018; 10:441. https://doi.org/10.3389/fnmol.2017.00441 PMID:29375304

53. Dinkova-Kostova AT, Kostov RV, Kazantsev AG. The role of Nrf2 signaling in counteracting neurodegenerative diseases. FEBS J. 2018; 285:357690.

https://doi.org/10.1111/febs.14379

PMID:29323772

54. Zhang B, Wang G, He J, Yang Q, Li D, Li J, Zhang F. Icariin attenuates neuroinflammation and exerts dopamine neuroprotection via an Nrf2-dependent manner. J Neuroinflammation. 2019; 16:92. https://doi.org/10.1186/s12974-019-1472-x PMID:31010422

55. Jin J, Wang H, Hua X, Chen D, Huang C, Chen Z. An outline for the pharmacological effect of icariin in the nervous system. Eur J Pharmacol. 2019; 842:20-32. https://doi.org/10.1016/i.ejphar.2018.10.006 PMID: 30342950

56. Ford GA. Clinical pharmacological issues in the development of acute stroke therapies. $\mathrm{Br}$ J Pharmacol. 2008 (Suppl 1); 153:S112-9. https://doi.org/10.1038/sj.bjp.0707654 PMID:18311155

57. Li L, Zhou QX, Shi JS. Protective effects of icariin on neurons injured by cerebral ischemia/reperfusion. Chin Med J (Engl). 2005; 118:1637-43.

PMID:16232349

58. Zheng M, Qu L, Lou Y. Effects of icariin combined with Panax notoginseng saponins on ischemia reperfusioninduced cognitive impairments related with oxidative stress and CA1 of hippocampal neurons in rat. Phytother Res. 2008; 22:597-604. https://doi.org/10.1002/ptr.2276 PMID:18398927

59. Kawabori M, Yenari MA. Inflammatory responses in brain ischemia. Curr Med Chem. 2015; 22:1258-77. https://doi.org/10.2174/09298673226661502091540 $\underline{36}$ PMID:25666795
60. Xiong D, Deng Y, Huang B, Yin C, Liu B, Shi J, Gong Q. Icariin attenuates cerebral ischemia-reperfusion injury through inhibition of inflammatory response mediated by NF-KB, PPAR $\alpha$ and PPARY in rats. Int Immunopharmacol. 2016; 30:157-62.

https://doi.org/10.1016/j.intimp.2015.11.035 PMID:26679678

61. Xu RX, Wu Q, Luo Y, Gong QH, Yu LM, Huang XN, Sun AS, Shi JS. Protective effects of icariin on cognitive deficits induced by chronic cerebral hypoperfusion in rats. Clin Exp Pharmacol Physiol. 2009; 36:810-5.

https://doi.org/10.1111/j.1440-1681.2009.05149.x PMID:19215241

62. Wang L, Zhang L, Chen ZB, Wu JY, Zhang X, Xu Y. Icariin enhances neuronal survival after oxygen and glucose deprivation by increasing SIRT1. Eur J Pharmacol. 2009; 609:40-4.

https://doi.org/10.1016/j.ejphar.2009.03.033 PMID:19303870

63. Zhu HR, Wang ZY, Zhu XL, Wu XX, Li EG, Xu Y. Icariin protects against brain injury by enhancing SIRT1dependent PGC-1alpha expression in experimental stroke. Neuropharmacology. 2010; 59:70-6. https://doi.org/10.1016/j.neuropharm.2010.03.017 PMID:20381504

64. Hammen C. Risk Factors for Depression: An Autobiographical Review. Annu Rev Clin Psychol. 2018; 14:1-28.

https://doi.org/10.1146/annurev-clinpsy-050817084811

PMID:29328780

65. Baune BT, Florea I, Ebert B, Touya M, Ettrup A, Hadi $M$, Ren $H$. Patient Expectations and Experiences of Antidepressant Therapy for Major Depressive Disorder: A Qualitative Study. Neuropsychiatr Dis Treat. 2021; 17:2995-3006.

https://doi.org/10.2147/NDT.S325954

PMID:34588779

66. Flint J, Kendler KS. The Genetics of Major Depression. Neuron. 2014; 81:1214.

https://doi.org/10.1016/j.neuron.2014.02.033

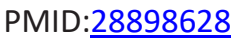

67. Grunebaum MF, Galfalvy HC, Choo TH, Keilp JG, Moitra VK, Parris MS, Marver JE, Burke AK, Milak MS, Sublette ME, Oquendo MA, Mann JJ. Ketamine for Rapid Reduction of Suicidal Thoughts in Major Depression: A Midazolam-Controlled Randomized Clinical Trial. Am J Psychiatry. 2018; 175:327-35.

https://doi.org/10.1176/appi.ajp.2017.17060647 PMID:29202655 
68. Malhi GS, Mann JJ. Depression. Lancet. 2018; 392:2299-312.

https://doi.org/10.1016/S0140-6736(18)31948-2 PMID:30396512

69. Cuijpers P, van Straten A, Andersson G, van Oppen P. Psychotherapy for depression in adults: a metaanalysis of comparative outcome studies. J Consult Clin Psychol. 2008; 76:909-22.

https://doi.org/10.1037/a0013075

PMID: 19045960

70. Strothers HS 3rd. Depression in the primary care setting. Ethn Dis. 2002; 12:S28-30.

PMID: 11913654

71. Xu D, Lu YR, Kou N, Hu MJ, Wang QS, Cui YL. Intranasal delivery of icariin via a nanogelthermoresponsive hydrogel compound system to improve its antidepressant-like activity. Int J Pharm. 2020; 586:119550.

https://doi.org/10.1016/j.ijpharm.2020.119550 PMID:32554031

72. Pan Y, Kong L, Xia X, Zhang W, Xia Z, Jiang F. Antidepressant-like effect of icariin and its possible mechanism in mice. Pharmacol Biochem Behav. 2005; 82:686-94.

https://doi.org/10.1016/j.pbb.2005.11.010 PMID:16380159

73. Zeng NX, Li HZ, Wang HZ, Liu KG, Gong XY, Luo WL, Yan C, Wu LL. Exploration of the mechanism by which icariin modulates hippocampal neurogenesis in a rat model of depression. Neural Regen Res. 2022; 17:632-42.

https://doi.org/10.4103/1673-5374.320993

PMID:34380904

74. Juruena MF, Bocharova $M$, Agustini $B$, Young $A H$. Atypical depression and non-atypical depression: Is HPA axis function a biomarker? A systematic review. J Affect Disord. 2018; 233:45-67.

https://doi.org/10.1016/i.jad.2017.09.052 PMID:29150144

75. Pan Y, Wang FM, Qiang LQ, Zhang DM, Kong LD. Icariin attenuates chronic mild stress-induced dysregulation of the LHPA stress circuit in rats. Psychoneuroendocrinology. 2010; 35:272-83. https://doi.org/10.1016/j.psyneuen.2009.06.020 PMID:19631474

76. Pan Y, Hong Y, Zhang QY, Kong LD. Impaired hypothalamic insulin signaling in CUMS rats: restored by icariin and fluoxetine through inhibiting CRF system. Psychoneuroendocrinology. 2013; 38:122-34.

https://doi.org/10.1016/i.psyneuen.2012.05.007 PMID:22663897
77. Wei K, Xu Y, Zhao Z, Wu X, Du Y, Sun J, Yi T, Dong J, Liu B. Icariin alters the expression of glucocorticoid receptor, FKBP5 and SGK1 in rat brains following exposure to chronic mild stress. Int J Mol Med. 2016; 38:337-44.

https://doi.org/10.3892/ijmm.2016.2591

PMID:27221032

78. Liu B, Zhang H, Xu C, Yang G, Tao J, Huang J, Wu J, Duan X, Cao Y, Dong J. Neuroprotective effects of icariin on corticosterone-induced apoptosis in primary cultured rat hippocampal neurons. Brain Res. 2011; 1375:59-67.

https://doi.org/10.1016/j.brainres.2010.12.053 PMID:21182828

79. Zhang H, Liu B, Wu J, Xu C, Tao J, Duan X, Cao Y, Dong J. Icariin inhibits corticosterone-induced apoptosis in hypothalamic neurons via the PI3-K/Akt signaling pathway. Mol Med Rep. 2012; 6:967-72.

https://doi.org/10.3892/mmr.2012.1041 PMID:22923091

80. Novais ARB, Crouzin N, Cavalier M, Boubal $M$, Guiramand J, Cohen-Solal C, de Jesus Ferreira MC, Cambonie G, Vignes M, Barbanel G. Tiagabine improves hippocampal long-term depression in rat pups subjected to prenatal inflammation. PLoS One. 2014; 9:e106302.

https://doi.org/10.1371/journal.pone.0106302 PMID:25184226

81. Huang $C$, Wang J, Lu X, Hu W, Wu F, Jiang B, Ling $Y$, Yang R, Zhang W. Z-guggulsterone negatively controls microglia-mediated neuroinflammation via blocking IкB- $\alpha-N F-$ KB signals. Neurosci Lett. 2016; 619:34-42.

https://doi.org/10.1016/j.neulet.2016.02.021

PMID:26879835

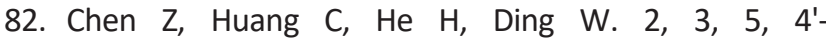
Tetrahydroxystilbene-2-O- $\beta$-D-glucoside prevention of lipopolysaccharide-induced depressive-like behaviors in mice involves neuroinflammation and oxido-nitrosative stress inhibition. Behav Pharmacol. 2017; 28:365-74. https://doi.org/10.1097/FBP.0000000000000307 PMID:28410266

83. Yang R, Wang P, Chen Z, Hu W, Gong Y, Zhang W, Huang C. WY-14643, a selective agonist of peroxisome proliferator-activated receptor- $\alpha$, ameliorates lipopolysaccharide-induced depressivelike behaviors by preventing neuroinflammation and oxido-nitrosative stress in mice. Pharmacol Biochem Behav. 2017; 153:97-104.

https://doi.org/10.1016/j.pbb.2016.12.010 PMID:28017641

84. Liu FG, Hu WF, Wang JL, Wang P, Gong Y, Tong L, Jiang B, Zhang W, Qin YB, Chen Z, Yang RR, Huang C. Z-Guggulsterone Produces Antidepressant-Like 
Effects in Mice through Activation of the BDNF Signaling Pathway. Int J Neuropsychopharmacol. 2017; 20:485-97.

https://doi.org/10.1093/ijnp/pyx009

PMID:28339691

85. Zeng KW, Fu H, Liu GX, Wang XM. Icariin attenuates lipopolysaccharide-induced microglial activation and resultant death of neurons by inhibiting TAK1/IKK/NFkappaB and JNK/p38 MAPK pathways. Int Immunopharmacol. 2010; 10:668-78.

https://doi.org/10.1016/i.intimp.2010.03.010 PMID:20347053

86. Guo J, Li F, Wu Q, Gong Q, Lu Y, Shi J. Protective effects of icariin on brain dysfunction induced by lipopolysaccharide in rats. Phytomedicine. 2010; 17:950-5.

https://doi.org/10.1016/j.phymed.2010.03.007 PMID:20382007

87. Gong MJ, Han B, Wang SM, Liang SW, Zou ZJ. Icariin reverses corticosterone-induced depression-like behavior, decrease in hippocampal brain-derived neurotrophic factor (BDNF) and metabolic network disturbances revealed by NMR-based metabonomics in rats. J Pharm Biomed Anal. 2016; 123:63-73.

https://doi.org/10.1016/j.jpba.2016.02.001

PMID:26874256

88. Wu J, Du J, Xu C, Le J, Xu Y, Liu B, Dong J. Icariin attenuates social defeat-induced down-regulation of glucocorticoid receptor in mice. Pharmacol Biochem Behav. 2011; 98:273-8.

https://doi.org/10.1016/j.pbb.2011.01.008 PMID:21256148

89. Li YC, Liu YM, Shen JD, Chen JJ, Pei YY, Fang XY. Resveratrol Ameliorates the Depressive-Like Behaviors and Metabolic Abnormalities Induced by Chronic Corticosterone Injection. Molecules. 2016; 21:1341.

https://doi.org/10.3390/molecules21101341

PMID:27754387

90. Shen JD, Wei Y, Li YJ, Qiao JY, Li YC. Curcumin reverses the depressive-like behavior and insulin resistance induced by chronic mild stress. Metab Brain Dis. 2017; 32:1163-72.

https://doi.org/10.1007/s11011-017-0017-1

PMID:28429187

91. Ishiwata S, Hattori K, Sasayama D, Teraishi T, Miyakawa T, Yokota Y, Matsumura R, Nishikawa T, Kunugi $H$. Cerebrospinal fluid $D$-serine concentrations in major depressive disorder negatively correlate with depression severity. J Affect Disord. 2018; 226:155-62. https://doi.org/10.1016/j.jad.2017.09.035

PMID:28985587

92. Liu $Y Y$, Zhou $X Y$, Yang LN, Wang HY, Zhang YQ, Pu JC, Liu LX, Gui SW, Zeng L, Chen JJ, Zhou CJ, Xie P. Social defeat stress causes depression-like behavior with metabolite changes in the prefrontal cortex of rats. PLoS One. 2017; 12:e0176725. https://doi.org/10.1371/journal.pone.0176725 PMID:28453574

93. Dobson R, Giovannoni G. Multiple sclerosis - a review. Eur J Neurol. 2019; 26:27-40. https://doi.org/10.1111/ene.13819 PMID:30300457

94. Reich DS, Lucchinetti CF, Calabresi PA. Multiple Sclerosis. N Engl J Med. 2018; 378:169-80.

https://doi.org/10.1056/NEJMra1401483

PMID:29320652

95. Wei Z, Wang $M$, Hong $M$, Diao S, Liu A, Huang $Y$, Yu $Q$, Peng Z. Icariin exerts estrogen-like activity in ameliorating EAE via mediating estrogen receptor $\beta$, modulating HPA function and glucocorticoid receptor expression. Am J Transl Res. 2016; 8:1910-8.

PMID:27186315

96. Wei Z, Deng X, Hong $M$, Su Q, Liu A, Huang Y, Yu Q, Peng $Z$. Icariin has synergistic effects with methylprednisolone to ameliorate EAE via modulating HPA function, promoting antiinflammatory and anti-apoptotic effects. Int J Clin Exp Med. 2015; 8:20188-97.

PMID:26884931

97. Zhang $Y$, Yin L, Zheng N, Zhang L, Liu J, Liang W, Wang $\mathrm{Q}$. Icariin enhances remyelination process after acute demyelination induced by cuprizone exposure. Brain Res Bull. 2017; 130:180-7.

https://doi.org/10.1016/j.brainresbull.2017.01.025 PMID:28161197

98. Shen R, Deng W, Li C, Zeng G. A natural flavonoid glucoside icariin inhibits Th1 and Th17 cell differentiation and ameliorates experimental autoimmune encephalomyelitis. Int Immunopharmacol. 2015; 24:224-31. https://doi.org/10.1016/j.intimp.2014.12.015 PMID:25528476

99. Cong $H$, Zhang $M$, Chang $H$, Du L, Zhang X, Yin L. Icariin ameliorates the progression of experimental autoimmune encephalomyelitis by down-regulating the major inflammatory signal pathways in a mouse relapse-remission model of multiple sclerosis. Eur J Pharmacol. 2020; 885:173523.

https://doi.org/10.1016/i.ejphar.2020.173523 PMID:32871176 
100. Melief J, de Wit SJ, van Eden CG, Teunissen C, Hamann J, Uitdehaag BM, Swaab D, Huitinga I. HPA axis activity in multiple sclerosis correlates with disease severity, lesion type and gene expression in normal-appearing white matter. Acta Neuropathol. 2013; 126:237-49.

https://doi.org/10.1007/s00401-013-1140-7 PMID:23812288

101. Trifunovic S, Stevanovic I, Milosevic A, Ristic N, Janjic M, Bjelobaba I, Savic D, Bozic I, Jakovljevic M, Tesovic K, Laketa D, Lavrnja I. The Function of the Hypothalamic-Pituitary-Adrenal Axis During Experimental Autoimmune Encephalomyelitis: Involvement of Oxidative Stress Mediators. Front Neurosci. 2021; 15:649485. https://doi.org/10.3389/fnins.2021.649485 PMID:34220419

102. Schosserer M, Grillari J, Wolfrum C, Scheideler M. AgeInduced Changes in White, Brite, and Brown Adipose Depots: A Mini-Review. Gerontology. 2018; 64:229-36. https://doi.org/10.1159/000485183 PMID:29212073

103. Vermeij WP, Dollé ME, Reiling E, Jaarsma D, PayanGomez C, Bombardieri CR, Wu H, Roks AJ, Botter SM, van der Eerden BC, Youssef SA, Kuiper RV, Nagarajah B, et al. Restricted diet delays accelerated ageing and genomic stress in DNA-repair-deficient mice. Nature. 2016; 537:427-31. https://doi.org/10.1038/nature19329 PMID:27556946

104. Liu P, Zhao H, Luo Y. Anti-Aging Implications of Astragalus Membranaceus (Huangqi): A Well-Known Chinese Tonic. Aging Dis. 2017; 8:868-86.

https://doi.org/10.14336/AD.2017.0816 PMID:29344421

105. Chen FJ, Liu B, Wu Q, Liu J, Xu YY, Zhou SY, Shi JS. Icariin Delays Brain Aging in Senescence-Accelerated Mouse Prone 8 (SAMP8) Model via Inhibiting Autophagy. J Pharmacol Exp Ther. 2019; 369:121-8. https://doi.org/10.1124/jpet.118.253310 PMID:30837279

106. Mecocci P, Boccardi V, Cecchetti R, Bastiani P, Scamosci M, Ruggiero C, Baroni M. A Long Journey into Aging, Brain Aging, and Alzheimer's Disease Following the Oxidative Stress Tracks. J Alzheimers Dis. 2018; 62:1319-35.

https://doi.org/10.3233/JAD-170732

PMID:29562533

107. Serrano-Pozo A, Frosch MP, Masliah E, Hyman BT. Neuropathological alterations in Alzheimer disease. Cold Spring Harb Perspect Med. 2011; 1:a006189. https://doi.org/10.1101/cshperspect.a006189 PMID:22229116
108. Erickson CA, Barnes CA. The neurobiology of memory changes in normal aging. Exp Gerontol. 2003; 38:61-9.

https://doi.org/10.1016/s0531-5565(02)00160-2 PMID:12543262

109. Yamasaki TR, Blurton-Jones M, Morrissette DA, Kitazawa M, Oddo S, LaFerla FM. Neural stem cells improve memory in an inducible mouse model of neuronal loss. J Neurosci. 2007; 27:11925-33. https://doi.org/10.1523/JNEUROSCI.1627-07.2007 PMID:17978032

110. Kitabatake Y, Sailor KA, Ming GL, Song H. Adult neurogenesis and hippocampal memory function: new cells, more plasticity, new memories? Neurosurg Clin N Am. 2007; 18:105-13. https://doi.org/10.1016/j.nec.2006.10.008 PMID: $\underline{17244558}$

111. Wu B, Chen Y, Huang J, Ning Y, Bian Q, Shan Y, Cai W, Zhang $X$, Shen $Z$. Icariin improves cognitive deficits and activates quiescent neural stem cells in aging rats. J Ethnopharmacol. 2012; 142:746-53. https://doi.org/10.1016/i.jep.2012.05.056 PMID:22687254

112. Oberdoerffer $P$, Sinclair DA. The role of nuclear architecture in genomic instability and ageing. Nat Rev Mol Cell Biol. 2007; 8:692-702. https://doi.org/10.1038/nrm2238 PMID:17700626

113. Westphal CH, Dipp MA, Guarente L. A therapeutic role for sirtuins in diseases of aging? Trends Biochem Sci. 2007; 32:555-60.

https://doi.org/10.1016/j.tibs.2007.09.008 PMID:17980602

114. Rogina B, Helfand SL. Sir2 mediates longevity in the fly through a pathway related to calorie restriction. Proc Natl Acad Sci U S A. 2004; 101:15998-6003. https://doi.org/10.1073/pnas.0404184101 PMID:15520384

115. Viswanathan M, Kim SK, Berdichevsky A, Guarente L. A role for SIR-2.1 regulation of ER stress response genes in determining C. elegans life span. Dev Cell. 2005; 9:605-15.

https://doi.org/10.1016/j.devcel.2005.09.017 PMID:16256736

116. Baur JA, Ungvari Z, Minor RK, Le Couteur DG, de Cabo R. Are sirtuins viable targets for improving healthspan and lifespan? Nat Rev Drug Discov. 2012; 11:443-61.

https://doi.org/10.1038/nrd3738

PMID:22653216

117. Li X, Khan I, Xia W, Huang G, Liu L, Law BYK, Yin L, Liao W, Leong W, Han R, Wong VKW, Xia C, Guo X, 
Hsiao WLW. Icariin enhances youth-like features by attenuating the declined gut microbiota in the aged mice. Pharmacol Res. 2021; 168:105587.

https://doi.org/10.1016/i.phrs.2021.105587 PMID: 33798737

118. Bergamini E. Autophagy: a cell repair mechanism that retards ageing and age-associated diseases and can be intensified pharmacologically. Mol Aspects Med. 2006; 27:403-10. https://doi.org/10.1016/j.mam.2006.08.001 PMID:16973211

119. Zheng J, Hu S, Wang J, Zhang $X$, Yuan D, Zhang C, Liu C, Wang $T$, Zhou $Z$. Icariin improves brain function decline in aging rats by enhancing neuronal autophagy through the AMPK/mTOR/ULK1 pathway. Pharm Biol. 2021; 59:183-91.

https://doi.org/10.1080/13880209.2021.1878238 PMID: 33556283

120. Kim JS, Yang M, Kim SH, Shin T, Moon C. Neurobiological toxicity of radiation in hippocampal cells. Histol Histopathol. 2013; 28:301-10.

https://doi.org/10.14670/HH-28.301 PMID:23348383

121. Shah DJ, Sachs RK, Wilson DJ. Radiation-induced cancer: a modern view. Br J Radiol. 2012; 85:e1166-73. https://doi.org/10.1259/bjr/25026140 PMID:23175483

122. Marazziti D, Baroni S, Catena-Dell'Osso M, Schiavi E, Ceresoli D, Conversano C, Dell'Osso L, Picano E. Cognitive, psychological and psychiatric effects of ionizing radiation exposure. Curr Med Chem. 2012; 19:1864-9. https://doi.org/10.2174/092986712800099776 PMID:22376039

123. Hatch $M$, Susser $M$. Background gamma radiation and childhood cancers within ten miles of a US nuclear plant. Int J Epidemiol. 1990; 19:546-52. https://doi.org/10.1093/ije/19.3.546 PMID:2262246

124. Sumner D. Low-level radiation--how dangerous is it? Med War. 1990; 6:112-9. https://doi.org/10.1080/07488009008408915 PMID:2215361

125. Ainsbury EA, Bouffler SD, Dörr W, Graw J, Muirhead CR, Edwards AA, Cooper J. Radiation cataractogenesis: a review of recent studies. Radiat Res. 2009; 172:1-9. https://doi.org/10.1667/RR1688.1 PMID: 19580502

126. Pastel RH. Radiophobia: long-term psychological consequences of Chernobyl. Mil Med. 2002 (Suppl 2); 167:134-6. https://doi.org/10.1093/milmed/167.suppl 1.134
PMID: 11873498

127. Dionisi $F$, Fiorica $F$, D'Angelo $E$, Maddalo $M$, Giacomelli I, Tornari E, Rosca A, Vigo F, Romanello D, Cianchetti M, Tommasino F, Massaccesi M, Orlandi E. Organs at risk's tolerance and dose limits for head and neck cancer re-irradiation: A literature review. Oral Oncol. 2019; 98:35-47. https://doi.org/10.1016/j.oraloncology.2019.08.017 PMID:31536844

128. Abe M. Charged particle radiotherapy at the Hyogo Ion Beam Medical Center: Characteristics, technology and clinical results. Proc Jpn Acad Ser B Phys Biol Sci. 2007; 83:151-63.

https://doi.org/10.2183/pjab.83.151 PMID:24367141

129. Combs SE, Kessel KA, Herfarth K, Jensen A, Oertel S, Blattmann C, Ecker S, Hoess A, Martin E, Witt O, Jäkel $O$, Kulozik AE, Debus J. Treatment of pediatric patients and young adults with particle therapy at the Heidelberg Ion Therapy Center (HIT): establishment of workflow and initial clinical data. Radiat Oncol. 2012; 7:170. https://doi.org/10.1186/1748-717X-7-170 PMID:23072718

130. Wertelecki W, Yevtushok L, Kuznietsov I, Komov O, Lapchenko S, Akhmedzanova D, Ostapchuk L. Chornobyl, radiation, neural tube defects, and microcephaly. Eur J Med Genet. 2018; 61:556-63. https://doi.org/10.1016/i.ejmg.2018.06.005 PMID:29908351

131. Singh VK, Newman VL, Romaine PL, Wise SY, Seed TM. Radiation countermeasure agents: an update (20112014). Expert Opin Ther Pat. 2014; 24:1229-55. https://doi.org/10.1517/13543776.2014.964684 PMID:25315070

132. Rosen EM, Day R, Singh VK. New approaches to radiation protection. Front Oncol. 2015; 4:381. https://doi.org/10.3389/fonc.2014.00381 PMID:25653923

133. Jagetia GC. Radioprotective Potential of Plants and Herbs against the Effects of Ionizing Radiation. J Clin Biochem Nutr. 2007; 40:74-81.

https://doi.org/10.3164/jcbn.40.74 PMID: 18188408

134. Phillips TL. Rationale for initial clinical trials and future development of radioprotectors. Cancer Clin Trials. 1980; 3:165-73. PMID: $\underline{6253097}$

135. Zhang WX, Wang HL, Wang R, Li R, He W, Zhang TB. [Chinese medicinal monomer and compound for 60Co-gamma-induced spermatogenic disturbance in mice]. Zhonghua Nan Ke Xue. 2010; 16:474-9. 
PMID:20684332

136. Zhang Y, Wei Y, Zhu Z, Gong W, Liu X, Hou Q, Sun Y, Chai J, Zou L, Zhou T. Icariin enhances radiosensitivity of colorectal cancer cells by suppressing NF-kB activity. Cell Biochem Biophys. 2014; 69:303-10. https://doi.org/10.1007/s12013-013-9799-x PMID:24590261

137. Hong J, Zhang Z, Lv W, Zhang M, Chen C, Yang S, Li S, Zhang L, Han D, Zhang W. Icaritin synergistically enhances the radiosensitivity of $4 \mathrm{~T} 1$ breast cancer cells. PLoS One. 2013; 8:e71347. https://doi.org/10.1371/journal.pone.0071347 PMID:23977023

138. Hwang E, Lin P, Ngo HTT, Gao W, Wang YS, Yu HS, Yi TH. Icariin and icaritin recover UVB-induced photoaging by stimulating Nrf2/ARE and reducing AP-1 and NF-KB signaling pathways: a comparative study on UVB-irradiated human keratinocytes. Photochem Photobiol Sci. 2018; 17:1396-408.

https://doi.org/10.1039/c8pp00174j

PMID:30225503

139. Moustafa EM, Moawed FSM, Abdel-Hamid GR. Icariin Promote Stem Cells Regeneration and Repair Acinar Cells in L-arginine / Radiation -Inducing Chronic Pancreatitis in Rats. Dose Response. 2020; 18:1559325820970810. https://doi.org/10.1177/1559325820970810 PMID:33192204

140. Wang SW, Ren BX, Qian F, Luo XZ, Tang X, Peng XC, Huang JR, Tang FR. Radioprotective effect of epimedium on neurogenesis and cognition after acute radiation exposure. Neurosci Res. 2019; 145:46-53.

https://doi.org/10.1016/j.neures.2018.08.011 PMID: $\underline{30145270}$

141. Park BK, Lee JH, Seo HW, Oh KS, Lee JH, Lee BH. Icariin protects against radiation-induced mortality and damage in vitro and in vivo. Int J Radiat Biol. 2019; 95:1094-102. https://doi.org/10.1080/09553002.2019.1589021 PMID:30831047

142. Hara T, Nakamura K, Matsui M, Yamamoto $A$, Nakahara Y, Suzuki-Migishima R, Yokoyama $M$, Mishima K, Saito I, Okano H, Mizushima N. Suppression of basal autophagy in neural cells causes neurodegenerative disease in mice. Nature. 2006; 441:885-9.

https://doi.org/10.1038/nature04724

PMID:16625204

143. Jiang $X$, Chen LL, Lan Z, Xiong F, Xu X, Yin YY, Li P, Wang $P$. Icariin Ameliorates Amyloid Pathologies by Maintaining Homeostasis of Autophagic Systems in
$A \beta_{1-42}$-Injected Rats. Neurochem Res. 2019; 44:2708-22.

https://doi.org/10.1007/s11064-019-02889-z PMID:31612304

144. Zeng R, Zhou Q, Zhang W, Fu X, Wu Q, Lu Y, Shi J, Zhou $S$. Icariin-mediated activation of autophagy confers protective effect on rotenone induced neurotoxicity in vivo and in vitro. Toxicol Rep. 2019; 6:637-44. https://doi.org/10.1016/j.toxrep.2019.06.014 PMID:31334034

145. Price DL, Tanzi RE, Borchelt DR, Sisodia SS. Alzheimer's disease: genetic studies and transgenic models. Annu Rev Genet. 1998; 32:461-93. https://doi.org/10.1146/annurev.genet.32.1.461 PMID:9928488

146. Ułamek-Kozioł M, Furmaga-Jabłońska W, Januszewski S, Brzozowska J, Sciślewska M, Jabłoński M, Pluta R. Neuronal autophagy: self-eating or selfcannibalism in Alzheimer's disease. Neurochem Res. 2013; 38:1769-73.

https://doi.org/10.1007/s11064-013-1082-4 PMID:23737325

147. Mo ZT, Li WN, Zhai YR, Gong QH. Icariin Attenuates OGD/R-Induced Autophagy via Bcl-2-Dependent Cross Talk between Apoptosis and Autophagy in PC12 Cells. Evid Based Complement Alternat Med. 2016; 2016:4343084.

https://doi.org/10.1155/2016/4343084 PMID:27610184

148. Eyre MD, Richter-Levin G, Avital A, Stewart MG. Morphological changes in hippocampal dentate gyrus synapses following spatial learning in rats are transient. Eur J Neurosci. 2003; 17:1973-80. https://doi.org/10.1046/j.1460-9568.2003.02624.x PMID:12752797

149. Louneva N, Cohen JW, Han LY, Talbot K, Wilson RS, Bennett DA, Trojanowski JQ, Arnold SE. Caspase-3 is enriched in postsynaptic densities and increased in Alzheimer's disease. Am J Pathol. 2008; 173:148895.

https://doi.org/10.2353/ajpath.2008.080434 PMID: $\underline{18818379}$

150. Li F, Zhang Y, Lu X, Shi J, Gong Q. Icariin improves the cognitive function of APP/PS1 mice via suppressing endoplasmic reticulum stress. Life Sci. 2019; 234:116739.

https://doi.org/10.1016/j.Ifs.2019.116739 PMID:31400352

151. Li H, Zhang X, Qi X, Zhu X, Cheng L. Icariin Inhibits Endoplasmic Reticulum Stress-induced Neuronal Apoptosis after Spinal Cord Injury through 
Modulating the PI3K/AKT Signaling Pathway. Int J Biol Sci. 2019; 15:277-86.

https://doi.org/10.7150/ijbs.30348

PMID:30745820

152. Li F, Gao B, Dong H, Shi J, Fang D. Icariin induces synoviolin expression through NFE2L1 to protect neurons from ER stress-induced apoptosis. PLoS One. 2015; 10:e0119955.

https://doi.org/10.1371/journal.pone.0119955 PMID:25806530

153. Chen L, Liu L, Yin J, Luo Y, Huang S. Hydrogen peroxide-induced neuronal apoptosis is associated with inhibition of protein phosphatase $2 \mathrm{~A}$ and 5 , leading to activation of MAPK pathway. Int J Biochem Cell Biol. 2009; 41:1284-95.

https://doi.org/10.1016/i.biocel.2008.10.029 PMID:19038359

154. Miller FD, Pozniak CD, Walsh GS. Neuronal life and death: an essential role for the p53 family. Cell Death Differ. 2000; 7:880-8. https://doi.org/10.1038/sj.cdd.4400736 PMID:11279533

155. Zhu X, Lee HG, Raina AK, Perry G, Smith MA. The role of mitogen-activated protein kinase pathways in Alzheimer's disease. Neurosignals. 2002; 11:270-81. https://doi.org/10.1159/000067426 PMID:12566928

156. Assefa Z, Vantieghem A, Garmyn M, Declercq W, Vandenabeele $P$, Vandenheede JR, Bouillon $R$, Merlevede W, Agostinis P. p38 mitogen-activated protein kinase regulates a novel, caspaseindependent pathway for the mitochondrial cytochrome c release in ultraviolet B radiationinduced apoptosis. J Biol Chem. 2000; 275:21416-21. https://doi.org/10.1074/jbc.M002634200 PMID:10748072

157. Li WW, Gao XM, Wang XM, Guo H, Zhang BL. Icariin inhibits hydrogen peroxide-induced toxicity through inhibition of phosphorylation of JNK/p38 MAPK and p53 activity. Mutat Res. 2011; 708:1-10. https://doi.org/10.1016/i.mrfmmm.2010.12.017 PMID:21236269

158. Abeyrathna $\mathrm{P}, \mathrm{Su} \mathrm{Y}$. The critical role of Akt in cardiovascular function. Vascul Pharmacol. 2015; 74:38-48.

https://doi.org/10.1016/j.vph.2015.05.008 PMID:26025205

159. Franke TF, Yang SI, Chan TO, Datta K, Kazlauskas A, Morrison DK, Kaplan DR, Tsichlis PN. The protein kinase encoded by the Akt proto-oncogene is a target of the PDGF-activated phosphatidylinositol 3kinase. Cell. 1995; 81:727-36. https://doi.org/10.1016/0092-8674(95)90534-0 PMID:

160. Baki L, Shioi J, Wen P, Shao Z, Schwarzman A, GamaSosa M, Neve R, Robakis NK. PS1 activates PI3K thus inhibiting GSK-3 activity and tau overphosphorylation: effects of FAD mutations. EMBO J. 2004; 23:2586-96. https://doi.org/10.1038/sj.emboj.7600251 PMID:15192701

161. Onyango IG, Bennett JP Jr, Tuttle JB. Endogenous oxidative stress in sporadic Alzheimer's disease neuronal cybrids reduces viability by increasing apoptosis through pro-death signaling pathways and is mimicked by oxidant exposure of control cybrids. Neurobiol Dis. 2005; 19:312-22. https://doi.org/10.1016/j.nbd.2005.01.026 PMID:15837587

162. Côté A, Chiasson M, Peralta MR 3rd, Lafortune K, Pellegrini L, Tóth K. Cell type-specific action of seizure-induced intracellular zinc accumulation in the rat hippocampus. J Physiol. 2005; 566:821-37. https://doi.org/10.1113/iphysiol.2005.089458 PMID:15919712

163. Brywe KG, Mallard C, Gustavsson M, Hedtjärn M, Leverin AL, Wang $X$, Blomgren $K$, Isgaard J, Hagberg $H$. IGF-I neuroprotection in the immature brain after hypoxia-ischemia, involvement of Akt and GSK3beta? Eur J Neurosci. 2005; 21:1489-502. https://doi.org/10.1111/j.1460-9568.2005.03982.x PMID:15845077

164. D'Astous M, Mendez P, Morissette M, Garcia-Segura LM, Di Paolo T. Implication of the phosphatidylinositol-3 kinase/protein kinase B signaling pathway in the neuroprotective effect of estradiol in the striatum of 1-methyl-4-phenyl1,2,3,6-tetrahydropyridine mice. Mol Pharmacol. 2006; 69:1492-8.

https://doi.org/10.1124/mol.105.018671

PMID:16434614

165. Mo ZT, Liao YL, Zheng J, Li WN. Icariin protects neurons from endoplasmic reticulum stress-induced apoptosis after OGD/R injury via suppressing IRE1 $\alpha$ XBP1 signaling pathway. Life Sci. 2020; 255:117847. https://doi.org/10.1016/j.Ifs.2020.117847 PMID:32470450

166. Kim TS, Pae CU, Yoon SJ, Jang WY, Lee NJ, Kim JJ, Lee SJ, Lee C, Paik IH, Lee CU. Decreased plasma antioxidants in patients with Alzheimer's disease. Int J Geriatr Psychiatry. 2006; 21:344-8.

https://doi.org/10.1002/gps.1469 PMID:16534775

167. Matsura T, Kai M, Fujii Y, Ito H, Yamada K. 
Hydrogen peroxide-induced apoptosis in HL-60 cells requires caspase-3 activation. Free Radic Res. 1999; 30:73-83.

https://doi.org/10.1080/10715769900300081

PMID:10193575

168. Zhang L, Huang S, Chen Y, Wang Z, Li E, Xu Y. Icariin inhibits hydrogen peroxide-mediated cytotoxicity by up-regulating sirtuin type 1-dependent catalase and peroxiredoxin. Basic Clin Pharmacol Toxicol. 2010; 107:899-905.

https://doi.org/10.1111/j.1742-7843.2010.00595.x

PMID:20533910

169. Attri P, Kumar N, Park JH, Yadav DK, Choi S, Uhm HS, Kim IT, Choi EH, Lee W. Influence of reactive species on the modification of biomolecules generated from the soft plasma. Sci Rep. 2015; 5:8221.

https://doi.org/10.1038/srep08221

PMID:25649786

170. Raghunath A, Sundarraj K, Arfuso F, Sethi G, Perumal E. Dysregulation of Nrf2 in Hepatocellular Carcinoma: Role in Cancer Progression and Chemoresistance. Cancers (Basel). 2018; 10:481. https://doi.org/10.3390/cancers10120481 PMID:30513925

171. Wang S, Zheng W, Liu X, Xue $P$, Jiang $S$, Lu D, Zhang Q, He G, Pi J, Andersen ME, Tan H, Qu W. lodoacetic acid activates Nrf2-mediated antioxidant response in vitro and in vivo. Environ Sci Technol. 2014; 48:13478-88.

https://doi.org/10.1021/es502855x

PMID:25332096

172. Zheng Y, Zhu G, He J, Wang G, Li D, Zhang F. Icariin targets Nrf2 signaling to inhibit microglia-mediated neuroinflammation. Int Immunopharmacol. 2019; 73:304-11.

https://doi.org/10.1016/j.intimp.2019.05.033

PMID:31128530

173. Hu X, Leak RK, Shi Y, Suenaga J, Gao Y, Zheng P, Chen J. Microglial and macrophage polarization-new prospects for brain repair. Nat Rev Neurol. 2015; 11:56-64.

https://doi.org/10.1038/nrneurol.2014.207 PMID:25385337

174. Liu L, Zhao Z, Lu L, Liu J, Sun J, Dong J. Icariin and icaritin ameliorated hippocampus neuroinflammation via mediating HMGB1 expression in social defeat model in mice. Int Immunopharmacol. 2019; 75:105799. https://doi.org/10.1016/j.intimp.2019.105799 PMID:31401387

175. Zhang ZY, Li C, Zug C, Schluesener HJ. Icariin ameliorates neuropathological changes, TGF- $\beta 1$ accumulation and behavioral deficits in a mouse model of cerebral amyloidosis. PLoS One. 2014; 9:e104616.

https://doi.org/10.1371/journal.pone.0104616 PMID:25101849

176. Yang WT, Zheng XW, Chen S, Shan CS, Xu QQ, Zhu JZ, Bao XY, Lin Y, Zheng GQ, Wang Y. Chinese herbal medicine for Alzheimer's disease: Clinical evidence and possible mechanism of neurogenesis. Biochem Pharmacol. 2017; 141:143-55. https://doi.org/10.1016/j.bcp.2017.07.002 PMID:28690138

177. Yadirgi G, Marino S. Adult neural stem cells and their role in brain pathology. J Pathol. 2009; 217:242-53. https://doi.org/10.1002/path.2480 PMID:19040211

178. Ming $G L$, Song $H$. Adult neurogenesis in the mammalian central nervous system. Annu Rev Neurosci. 2005; 28:223-50. https://doi.org/10.1146/annurev.neuro.28.051804.1 $\underline{01459}$

PMID:16022595

179. Ming $G L$, Song $H$. Adult neurogenesis in the mammalian brain: significant answers and significant questions. Neuron. 2011; 70:687-702. https://doi.org/10.1016/j.neuron.2011.05.001 PMID:21609825

180. Kempermann G, Gage FH, Aigner L, Song H, Curtis MA, Thuret S, Kuhn HG, Jessberger S, Frankland PW, Cameron HA, Gould E, Hen R, Abrous DN, et al. Human Adult Neurogenesis: Evidence and Remaining Questions. Cell Stem Cell. 2018; 23:25-30. https://doi.org/10.1016/i.stem.2018.04.004 PMID:29681514

181. Dong H, Goico B, Martin M, Csernansky CA, Bertchume A, Csernansky JG. Modulation of hippocampal cell proliferation, memory, and amyloid plaque deposition in APPsw (Tg2576) mutant mice by isolation stress. Neuroscience. 2004; 127:601-9. https://doi.org/10.1016/j.neuroscience.2004.05.040 PMID:15283960

182. Tsai KJ, Tsai YC, Shen CK. G-CSF rescues the memory impairment of animal models of Alzheimer's disease.

J Exp Med. 2007; 204:1273-80.

https://doi.org/10.1084/jem.20062481 PMID:17517969

183. Verret L, Trouche S, Zerwas M, Rampon C. Hippocampal neurogenesis during normal and pathological aging. Psychoneuroendocrinology. 2007 (Suppl 1); 32:S26-30. https://doi.org/10.1016/j.psyneuen.2007.04.014 PMID:17629417 
184. Lazarov O, Demars MP. All in the Family: How the APPs Regulate Neurogenesis. Front Neurosci. 2012; 6:81.

https://doi.org/10.3389/fnins.2012.00081 PMID:22675290

185. Neves G, Cooke SF, Bliss TV. Synaptic plasticity, memory and the hippocampus: a neural network approach to causality. Nat Rev Neurosci. 2008; 9:6575.

https://doi.org/10.1038/nrn2303

PMID:18094707

186. Zhao C, Deng W, Gage FH. Mechanisms and functional implications of adult neurogenesis. Cell. 2008; 132:645-60.

https://doi.org/10.1016/i.cell.2008.01.033 PMID:18295581

187. Trouche S, Bontempi B, Roullet P, Rampon C. Recruitment of adult-generated neurons into functional hippocampal networks contributes to updating and strengthening of spatial memory. Proc Natl Acad Sci U S A. 2009; 106:5919-24. https://doi.org/10.1073/pnas.0811054106 PMID:19321751

188. Hollands C, Bartolotti N, Lazarov O. Alzheimer's Disease and Hippocampal Adult Neurogenesis; Exploring Shared Mechanisms. Front Neurosci. 2016; 10:178.

https://doi.org/10.3389/fnins.2016.00178 PMID:27199641

189. Liu D, Ye Y, Xu L, Yuan W, Zhang Q. Icariin and mesenchymal stem cells synergistically promote angiogenesis and neurogenesis after cerebral ischemia via PI3K and ERK1/2 pathways. Biomed Pharmacother. 2018; 108:663-9. https://doi.org/10.1016/j.biopha.2018.09.071 PMID:30245466

190. Yang $P$, Guan YQ, Li YL, Zhang L, Zhang L, Li L. Icariin promotes cell proliferation and regulates gene expression in human neural stem cells in vitro. Mol Med Rep. 2016; 14:1316-22.

https://doi.org/10.3892/mmr.2016.5377 PMID:27278906

191. Fu X, Li S, Zhou S, Wu Q, Jin F, Shi J. Stimulatory effect of icariin on the proliferation of neural stem cells from rat hippocampus. BMC Complement Altern Med. 2018; 18:34. https://doi.org/10.1186/s12906-018-2095-y PMID:29378551

192. Li L, Clevers H. Coexistence of quiescent and active adult stem cells in mammals. Science. 2010; 327:542-5. https://doi.org/10.1126/science.1180794
PMID:20110496

193. Ma D, Zhao L, Zhang L, Li Y, Zhang L, Li L. Icariin Promotes Survival, Proliferation, and Differentiation of Neural Stem Cells In Vitro and in a Rat Model of Alzheimer's Disease. Stem Cells Int. 2021; 2021:9974625. https://doi.org/10.1155/2021/9974625 PMID: $\underline{34257671}$

194. Fu M, Liu M, Sauve AA, Jiao X, Zhang X, Wu X, Powell MJ, Yang T, Gu W, Avantaggiati ML, Pattabiraman N, Pestell TG, Wang F, et al. Hormonal control of androgen receptor function through SIRT1. Mol Cell Biol. 2006; 26:8122-35. https://doi.org/10.1128/MCB.00289-06 PMID:16923962

195. Hasegawa K, Yoshikawa K. Necdin regulates p53 acetylation via Sirtuin1 to modulate DNA damage response in cortical neurons. J Neurosci. 2008; 28:8772-84.

https://doi.org/10.1523/JNEUROSCI.3052-08.2008 PMID:18753379

196. Zschoernig B, Mahlknecht U. SIRTUIN 1: regulating the regulator. Biochem Biophys Res Commun. 2008; 376:251-5. https://doi.org/10.1016/j.bbrc.2008.08.137 PMID:18774777

197. Hallows WC, Albaugh BN, Denu JM. Where in the cell is SIRT3?--functional localization of an NAD+dependent protein deacetylase. Biochem J. 2008; 411:e11-3.

https://doi.org/10.1042/BJ20080336

PMID:18363549

198. Weir HJ, Murray TK, Kehoe PG, Love S, Verdin EM, O'Neill MJ, Lane JD, Balthasar N. CNS SIRT3 expression is altered by reactive oxygen species and in Alzheimer's disease. PLoS One. 2012; 7:e48225. https://doi.org/10.1371/journal.pone.0048225 PMID:23139766

199. Zeng R, Wang X, Zhou Q, Fu X, Wu Q, Lu Y, Shi J, Klaunig JE, Zhou S. Icariin protects rotenone-induced neurotoxicity through induction of SIRT3. Toxicol Appl Pharmacol. 2019; 379:114639.

https://doi.org/10.1016/j.taap.2019.114639 PMID:31251943

200. Wareski P, Vaarmann A, Choubey V, Safiulina D, Liiv J, Kuum M, Kaasik A. PGC-1\{alpha\} and PGC-1\{beta\} regulate mitochondrial density in neurons. J Biol Chem. 2009; 284:21379-85.

https://doi.org/10.1074/jbc.M109.018911 PMID:19542216

201. Scarpulla RC. Transcriptional paradigms in mammalian mitochondrial biogenesis and function. 
Physiol Rev. 2008; 88:611-38.

https://doi.org/10.1152/physrev.00025.2007

PMID:18391175

202. Lin JD. Minireview: the PGC-1 coactivator networks: chromatin-remodeling and mitochondrial energy metabolism. Mol Endocrinol. 2009; 23:2-10.

https://doi.org/10.1210/me.2008-0344 PMID:19008463

203. St-Pierre J, Drori S, Uldry M, Silvaggi JM, Rhee J, Jäger S, Handschin C, Zheng K, Lin J, Yang W, Simon DK, Bachoo R, Spiegelman BM. Suppression of reactive oxygen species and neurodegeneration by the PGC-1 transcriptional coactivators. Cell. 2006; 127:397-408.

https://doi.org/10.1016/i.cell.2006.09.024 PMID:17055439

204. Cantó C, Auwerx J. PGC-1alpha, SIRT1 and AMPK, an energy sensing network that controls energy expenditure. Curr Opin Lipidol. 2009; 20:98-105. https://doi.org/10.1097/MOL.0b013e328328d0a4 PMID: 19276888

205. Nemoto S, Fergusson MM, Finkel T. SIRT1 functionally interacts with the metabolic regulator and transcriptional coactivator PGC-1\{alpha\}. J Biol Chem. 2005; 280:16456-60. https://doi.org/10.1074/ibc.M501485200 PMID:15716268

206. Vetterkind S, Poythress RH, Lin QQ, Morgan KG. Hierarchical scaffolding of an ERK1/2 activation pathway. Cell Commun Signal. 2013; 11:65. https://doi.org/10.1186/1478-811X-11-65 PMID:23987506

207. Eastwood SL, Harrison PJ. Interstitial white matter neuron density in the dorsolateral prefrontal cortex and parahippocampal gyrus in schizophrenia. Schizophr Res. 2005; 79:181-8. https://doi.org/10.1016/j.schres.2005.07.001 PMID: 16076548

208. Pak JH, Huang FL, Li J, Balschun D, Reymann KG, Chiang $\mathrm{C}$, Westphal $\mathrm{H}$, Huang KP. Involvement of neurogranin in the modulation of calcium/ calmodulin-dependent protein kinase II, synaptic plasticity, and spatial learning: a study with knockout mice. Proc Natl Acad Sci U S A. 2000; 97:11232-7. https://doi.org/10.1073/pnas.210184697 PMID:11016969
209. Zheng XX, Chen YW, Yue YS, Li YC, Xia SZ, Li Y, Deng $\mathrm{HH}, \mathrm{He} \mathrm{J}, \mathrm{Cao}$ YJ. Icariin ameliorates learning and memory impairments through ERK/CaMKIl $\alpha / C R E B$ signaling and HPA axis in prenatally stressed female offspring. Biomed Pharmacother. 2019; 117:109077. https://doi.org/10.1016/j.biopha.2019.109077 PMID: 31177064

210. Cong $H$, Liang $M$, Wang $Y$, Chang $H$, Du L, Zhang $X$, Yin L. Icariin ameliorates the cuprizone-induced acute brain demyelination and modulates the number of oligodendrocytes, microglia and astrocytes in the brain of C57BL/6J mice. Brain Res Bull. 2021; 175:37-47.

https://doi.org/10.1016/j.brainresbull.2021.07.010 PMID:34274431

211. Lin HM, Lin LF, Sun MY, Liu J, Wu Q. Topical Delivery of Four Neuroprotective Ingredients by EthosomeGel: Synergistic Combination for Treatment of Oxaliplatin-Induced Peripheral Neuropathy. Int J Nanomedicine. 2020; 15:3251-66.

https://doi.org/10.2147/IJN.S233747 PMID:32440122

212. Zhang $Y, X u$ R, Li X, Tan $Q$, Huang $P$, Zhang $Y$, Qin $M$, Ren $L$. Effects of icariin on long noncoding RNA and mRNA expression profile in the aortas of apoEdeficient mice. Biosci Rep. 2019; 39:BSR20190855. https://doi.org/10.1042/BSR20190855 PMID:31296789 